\title{
Phytotoxins Produced by Fungi Associated with Grapevine Trunk Diseases
}

\author{
Anna Andolfi ${ }^{1, *}$, Laura Mugnai ${ }^{2, *}$, Jordi Luque ${ }^{3}$, Giuseppe Surico ${ }^{2}$, Alessio Cimmino ${ }^{1}$ and \\ Antonio Evidente ${ }^{1}$
}

1 Dipartimento di Scienze del Suolo, della Pianta, dell'Ambiente e delle Produzioni Animali, Università di Napoli Federico II, Via Università 100, Portici I-80055, Italy;

E-Mails: alessio.cimmino@unina.it (A.C.); evidente@unina.it (A.E.)

2 Dipartimento di Biotecnologie Agrarie, Sezione Protezione delle piante, Università degli Studi di Firenze, P.le delle Cascine 28, Firenze I-50144, Italy; E-Mail: giuseppe.surico@unifi.it

3 Departament de Patologia Vegetal, IRTA, Ctra. de Cabrils km 2, Cabrils E-08348, Spain; E-Mail: jordi.luque@irta.cat

* Authors to whom correspondence should be addressed; E-Mails: andolfi@unina.it (A.A.); laura.mugnai@unifi.it (L.M.); Tel.: +39-081-2539-179 (A.A.); +39-055-3288-274 (L.M.); Fax: +39-081-2539-186 (A.A.); +39-055-3288-273 (L.M.).

Received: 8 November 2011; in revised form: 29 November 2011 / Accepted: 30 November 2011 / Published: 20 December 2011

\begin{abstract}
Up to 60 species of fungi in the Botryosphaeriaceae family, genera Cadophora, Cryptovalsa, Cylindrocarpon, Diatrype, Diatrypella, Eutypa, Eutypella, Fomitiporella, Fomitiporia, Inocutis, Phaeoacremonium and Phaeomoniella have been isolated from decline-affected grapevines all around the World. The main grapevine trunk diseases of mature vines are Eutypa dieback, the esca complex and cankers caused by the Botryospheriaceae, while in young vines the main diseases are Petri and black foot diseases. To understand the mechanism of these decline-associated diseases and the symptoms associated with them, the toxins produced by the pathogens involved in these diseases were isolated and characterised chemically and biologically. So far the toxins of only a small number of these decline fungi have been studied. This paper presents an overview of the toxins produced by the most serious of these vine wood pathogens: Eutypa lata, Phaeomoniella chlamydospora, Phaeoacremonium aleophilum and some taxa in the Botryosphaeriaceae family, and examines how these toxins produce decline symptoms. The chemical structure of these metabolites and in some cases their vivotoxin nature are also discussed.
\end{abstract}


Keywords: black dead arm; Botryosphaeria canker; esca; Eutypa dieback; eutypiosis; grapevine trunk diseases; phytotoxins; Phaeomoniella; Phaeoacremonium; Fomitiporia

\section{Introduction}

Grapevine trunk diseases cause a slow decline and yield loss in grapevines at all stages of growth. The symptoms of these diseases include the death of spurs, arms, and cordons, and the eventual death of the vines due to a progressive wood necrosis and decay of plant tissue [1-6]. Besides causing various types of wood necrosis and decay, most of these diseases also produce leaf symptoms, which include chlorosis, necrosis, deformation, and stunting.

Many fungi are involved in grapevine trunk diseases. They include species in the Botryosphaeriaceae, which cause dieback and canker, Eutypa lata, the agent of Eutypa dieback or eutypiosis, species of Cylindrocarpon and Campylocarpon, causing black foot disease, Phaeomoniella chlamydospora and Phaeoacremonium aleophilum, the main agents of the vascular diseases within the esca complex, including Petri disease, and species of Fomitiporia, Fomitiporella, Inocutis and other basidiomycetes, causing wood decay [1,3-7]. Recent research has established that, besides E. lata, some other species also in the family Diatrypaceae likewise cause trunk diseases of grapevine. These are Eutypa leptoplaca, Cryptovalsa ampelina, Cryptosphaeria pullmanensis, and some further species in the genera Diatrype, Diatrypella and Eutypa [8,9]. Most of these fungi grow slowly in the vine wood, and foliar symptoms do not appear until several years after the onset of infection, so that by the time the symptoms become visible the fungi are well-established $[2,6,10]$.

In addition, pathogenicity has been confirmed recently for some less well-known fungi such as Cadophora luteo-olivacea $[11,12]$, but many characteristic factors regarding the pathogenicity of these fungi and their mechanism of action remain to be investigated.

There is no effective cure for grapevine trunk diseases, but some remedial practices on affected vines are possible; these include the removal of dead vine parts, and re-training or re-grafting affected vines $[13,14]$. Moreover, the application of chemical and biological protectants on pruning wounds has been recommended to reduce the spread of these diseases [15-19]. Some grapevine trunk pathogens can also infect the grapevine material used in the propagation process of vines. An integrated management program including hot water treatment of vine propagation material, and the application of chemical pesticides and/or biocontrol agents at different growth stages of new vines have shown some interesting results in controlling these diseases [20-22].

Several pathogens involved in grapevine trunk diseases produce toxic metabolites. Many of these metabolites have been chemically characterised and tested for their toxicity on the protoplasts, calli and leaves of various Vitis species and on $V$. vinifera cultivars. The mode of action of some of these metabolites is well documented. This review examines the role of these toxic metabolites, the factors that ensure their virulence and their mode of action. 


\section{Eutypa Dieback}

Eutypa lata causes Eutypa dieback, a serious disease that has been known for over 60 years. It causes losses in older vineyards. Its most recognised symptoms are: stunting of new shoots early in the growing season, small, cupped, chlorotic and tattered leaves, and short internodes (Figure 1A,B). Internal wood symptoms when arms and trunks are cross-sectioned include characteristic V-shaped necrosis (Figure 1C). External cankers developing from old pruning wounds also occur $[1,23]$.

Figure 1. Symptoms of Eutypa dieback in (A) vine leaves and (B) new vine shoots; (C) Characteristic V-shaped necrosis of a vine trunk.

(A)

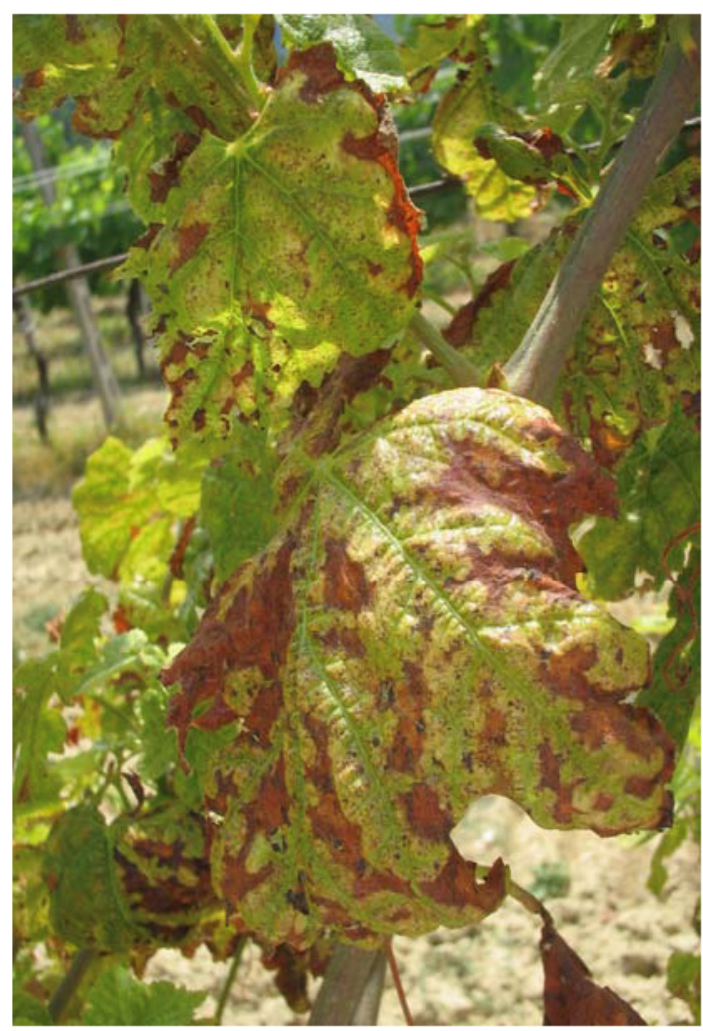

(B)

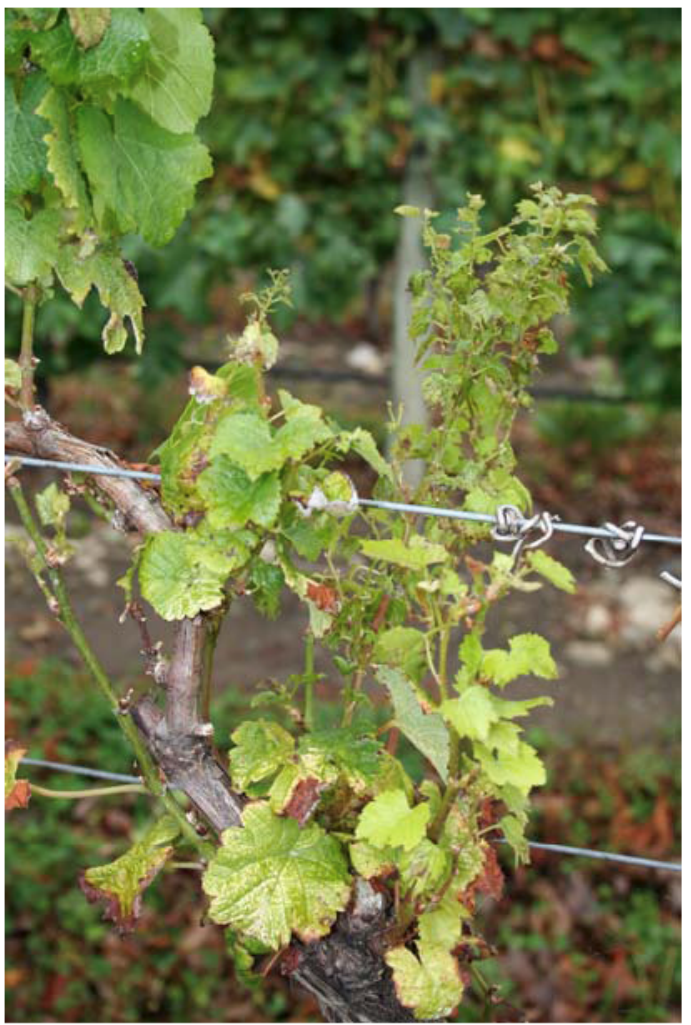

(C)

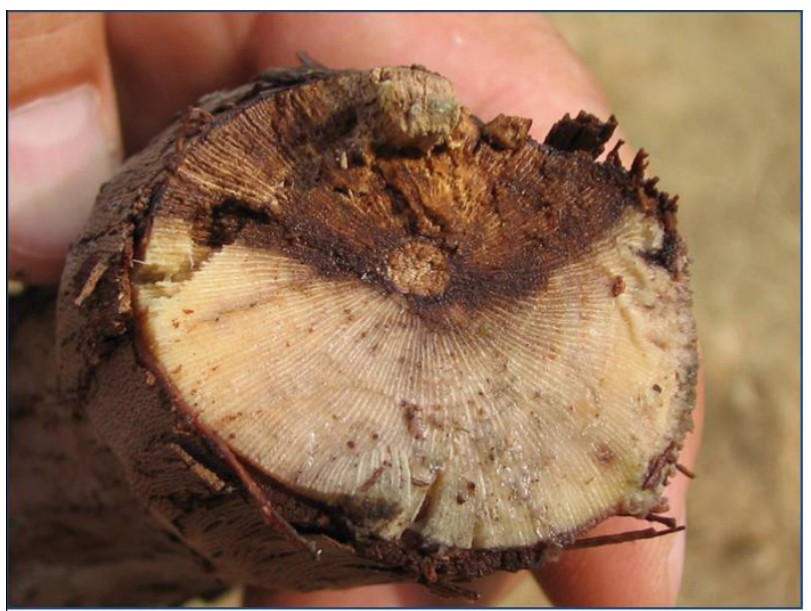




\subsection{Toxins Produced by Eutypa lata}

Eutypa lata produces a number of structurally related secondary metabolites, mainly acetylenic phenols and their heterocyclic analogues. Eutypine (1, Figure 2), or 4-hydroxy-3-(3-methylbut-3-ene1 -ynyl)-benzaldehyde, is the most toxic. It was isolated from the cultures of an unspecified strain of E. lata and characterised [24,25]. It has an unusual five-carbon acetylenic side chain. Some other, structurally related metabolites were isolated from organic extracts of the same fungal culture such as eutypinol, $O$-methyleutypin, $O$-methyleutypinol, eutypin carboxylic acid analogue (2-5, Figure 2 ), as well as the compounds produced by hydroxylation of the terminal vinyl group of eutypine, eutypinol and the carboxylic anologue (6-8, Figure 2) [25-27]. Under low acidic conditions, eutypine is converted into 2-iso-propenyl-5-formylbenzofuran (9, Figure 2). This bicyclic product was also detected in E. lata culture filtrates [26].

Figure 2. Chemical structures of Eutypa lata metabolites and derivatives: eutypine, eutypinol, $O$-methyleutypine, $O$-methyleutypinol, eutypin carboxylic acid analogue (1-5), 3-(3,4-dihydroxy-3-methyl-1-butynyl)-4-hydroxy-benzaldehyde, 2-(3,4-dihydroxy-3-methyl1-butynyl)-4-hydroxymethyl-phenol, 3-(3,4-dihydroxy-3-methyl-1-butynyl)-4-hydroxy-benzoic acid (6-8), 2-iso-propenyl-5-formylbenzofuran, siccayne, eulatinol (9-11), eulatachromene and its derivatives (12 and 17-19), epoxidised chromanones (13-14), eutypoxide B and allenic epoxycyclohexane (15-16).

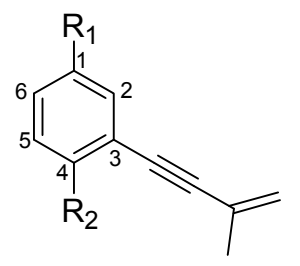

$1 \mathrm{R}_{1}=\mathrm{CHO}, \mathrm{R}_{2}=\mathrm{OH}$

$2 \mathrm{R}_{1}=\mathrm{CH}_{2} \mathrm{OH}, \mathrm{R}_{2}=\mathrm{OH}$

$3 \mathrm{R}_{1}=\mathrm{CHO}, \mathrm{R}_{2}=\mathrm{OCH}_{3}$

$4 \mathrm{R}_{1}=\mathrm{CH}_{2} \mathrm{OH}, \mathrm{R}_{2}=\mathrm{OCH}_{3}$

$5 \mathrm{R}_{1}=\mathrm{COOH}, \mathrm{R}_{2}=\mathrm{OH}$<smiles>[R]c1ccc(O)cc1C#CC(=C)C</smiles>

$10 \mathrm{R}=\mathrm{OH}$ $11 \mathrm{R}=\mathrm{OCH}_{3}$<smiles>CC1(C)CC(=O)C2=C(C[C@H](O)[C@H]3O[C@H]23)O1</smiles>

14<smiles>[R1]c1ccc(O)c(C#CC(C)(O)CO)c1</smiles>

$6 \mathrm{R}_{1}=\mathrm{CHO}$

$7 \mathrm{R}_{1}=\mathrm{CH}_{2} \mathrm{OH}$

$8 \mathrm{R}_{1}=\mathrm{COOH}$

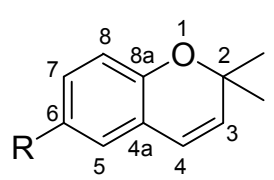

$12 \mathrm{R}=\mathrm{CH}_{2} \mathrm{OH}$

$17 \mathrm{R}=\mathrm{CHO}$

$18 \mathrm{R}=\mathrm{COOH}$

$19 \mathrm{R}=\mathrm{COOCH}_{3}$<smiles>CC(C)=CC(=O)[C@@H]1C[C@H](O)[C@H]2O[C@H]2[C@H]1O</smiles>

15<smiles>C=C(C)c1cc2cc(C=O)ccc2o1</smiles>

9<smiles>CC1(C)CC(=O)C2=C(O1)C(O)C1OC1C2</smiles>

13<smiles></smiles>

16 
Biological assays on excised tomato plants and vine leaves have shown that of all these metabolites eutypine is the most phytotoxic [26]. A comparative study was carried out on the metabolites from three strains of E. lata: strain E120 from grapevine in California, strain E125 from grapevine in Italy, and isolate E178 from oak in California. The metabolites were grown on malt yeast broth (MYB) and on potato dextrose broth (PDB) [27]. Eutypine, occurred in only one of the strains but the main metabolite was eutypinol, which is a detoxification product of 1 (Figure 2) [27]. A novel metabolite, named eulatinol (11, Figure 2) was isolated from the Italian strain E125, together with its $O$-demethyl derivate, siccayene (10, Figure 2). The chromene analogue, 6-hydroxymethyl-2,2dimethyl-2H-chromene, named eulatachromene (12, Figure 2) as well as $\mathbf{1}$ and $\mathbf{2}$ (Figure 2) were isolated from the California strain E120 [18]. As previously reported, eutypine was readily cyclised into benzofuran (9, Figure 2) in the presence of traces of acid, and eutypinol was the main metabolite under most culture conditions [27].

The phytotoxicity of E. lata metabolites was tested in a leaf disk bioassay on "Cabernet Sauvignon" leaves (Figure 3A) [28]. Activity at $50 \mu \mathrm{g} / \mathrm{mL}$ of metabolites 1, 2, and 9-12 (Figure 2) indicated that neither eutypinol nor siccayne were phytotoxic; while eutypine, benzofuran, eulatinol, and eulatacromene $(\mathbf{1}, \mathbf{9}, 11$ and 12, Figure 2) had a toxic effect, producing necrotic spots on the leaves (Figure 3A). Eulatacromene and benzofuran were more toxic than the acetylenic phenols. However eulatachromene (12, Figure 2) was also examined for toxicity at various concentrations from 10 to $100 \mu \mathrm{g} / \mathrm{mL}$. At its lowest concentration, 12 (Figure 2) caused necrosis on some disks, and at its highest concentration it caused necrosis on all disks (Figure 3B) [28].

Two highly oxygenated cyclohexene oxides were also isolated from E. lata: eutypoxide B [29] and the novel allenic epoxycyclohexane (13 and 14, Figure 2) [25].

Figure 3. (A) Comparison, after $24 \mathrm{~h}$ and at $50 \mu \mathrm{g} / \mathrm{mL}$, of the toxicity of the methanol control (C) and of the primary metabolites eutypine 1, eutypinol 2, 2-iso-propenyl-5formylbenzofuran 9, siccayene $\mathbf{1 0}$, eulatinol 11, and eulatachromene 12, in a grape leaf bioassay; (B) comparison, after $24 \mathrm{~h}$ and at $10,25,50$ and $100 \mu \mathrm{g} / \mathrm{mL}$, of phytotoxicity of the methanol control (C) and eulatachromene (12) (redrawn with modifications from Figure 5 in [28]).

(A)
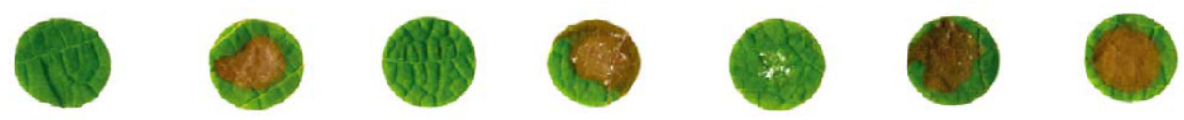

C

1

2

9

10
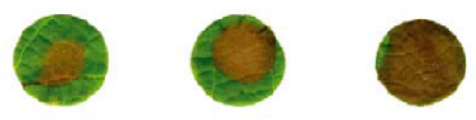

C

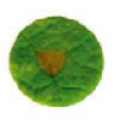

10
25

50

$100 \mu \mathrm{g} / \mathrm{ml}$

To elucidate the biochemistry of $E$. lata, both its sterol composition and its total sterol content were investigated in solid and in liquid culture [30]. The total amount of sterols was 1.58 and $1.12 \mu \mathrm{g} / \mathrm{mg}$ 
dry weight mycelium in solid and liquid cultures respectively. The major sterol was identified as ergosterol. This accounted for $88 \%$ of the total sterols in a solid medium and $78 \%$ when the fungus was grown in a liquid medium. In addition to ergosterol, four minor sterols, ergosta-5,7,9(11),22-tetraen$3 \beta$-ol, ergosta-7,22-dien-3 $\beta$-ol, fecosterol and episterol also occurred. They accounted for $1-4 \%$ and $1.8-13 \%$ in solid and liquid culture respectively. These results suggest that the sterol biosynthesis pathway of E. lata is very similar to that of other pathogenic filamentous fungi [30].

\subsection{Structure-Toxicity Relationship Studies}

Preliminary studies on the structure-toxicity relationship, carried out on the acetylenic phenols, showed that the occurrence of the aldehydic group and a free $\mathrm{OH}$ group in para-position were important for phytotoxic activity [26].

Smith et al. [31] in their study of the structure-phytotoxicity relationships compared the activity of metabolites from various strains of E. lata and from their chromene analogues, such as the corresponding aldehyde, acid and methyl esters (17-19, Figure 2) [31]. They synthesised the chromene analogue in quantities sufficient for evaluation, and carried out a rapid quantitative bioassay, involving the topical application of individual compounds to culture disks of grape leaves with subsequent measurement of chlorophyll loss to measure tissue damage (Figure 4A,B) [31]. In this assay, eulatachromene was more phytotoxic than eutypine (Figure 4A). The bicyclic product 9 (Figure 2) was also quite toxic, while the reduction product eutypinol, as well as the quinol siccayne (Figure 4A), were not toxic [31]. When eulatachromene was compared with its three synthetic analogues 17-19 (Figure 2) only the corresponding aldehyde 17 (Figure 2) had a toxicity similar to 12 (Figure 2), while 18 and 19 (Figure 2) were not toxic (Figure 4B) [31]. Consequently the active chromenes 12 and 17, along with benzofuran 9 (Figure 2), were more toxic than eutypine and eutypinol [31].

Figure 4. Toxicity of metabolites of Eutypa lata and their synthetic analogues measured in the grapeleaf disk bioassay as a per-cent reduction in chlorophyll relative to the control. (A) E. lata metabolites eutypine, eutypinol, 2-iso-propenyl-5-formylbenzofuran, siccayne and eulatachromene (1, 2, 9, 10 and 12, Figure 2). (B) Eulatachromene and its synthetic analogues 6-carboxymethylchromene, 6-formylchromene, and 6-carboxychromene (12, 17-19, Figure 2) (redrawn with modifications from Figure 5 in [31]).
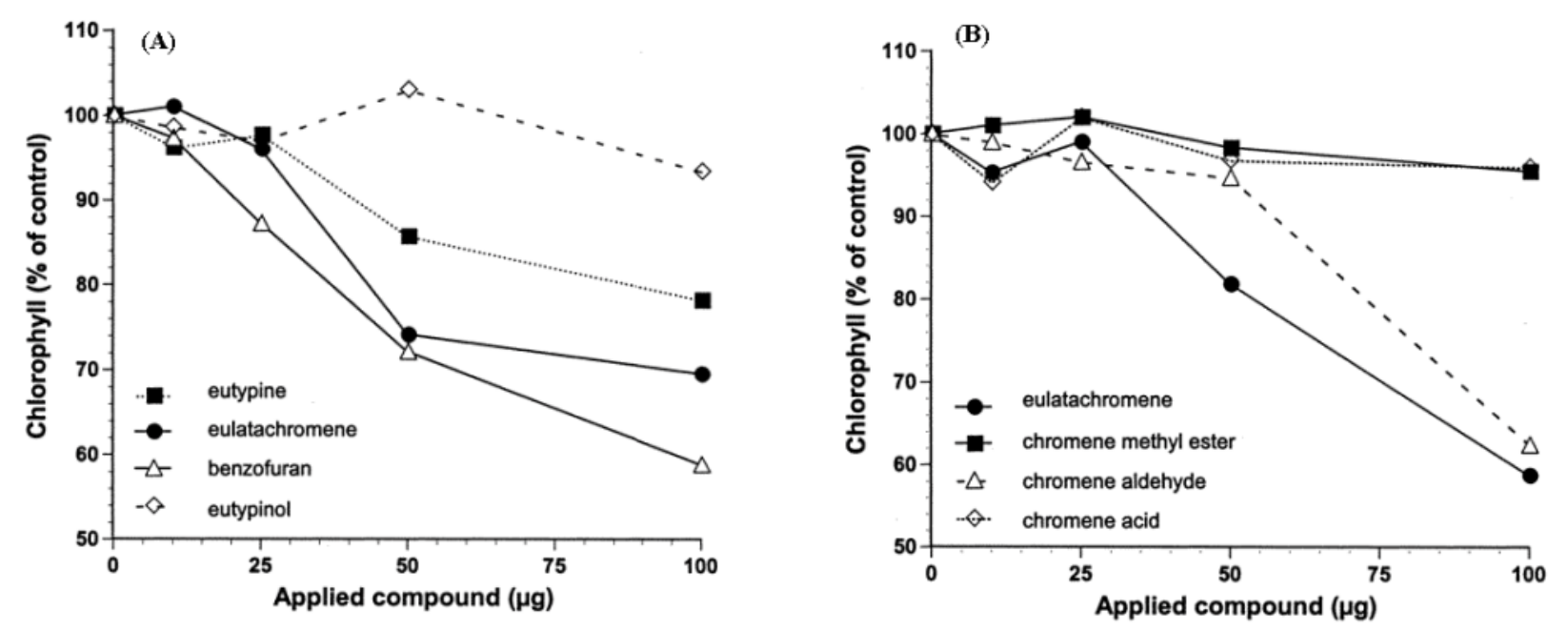


\subsection{Mechanism of Action of Eutypa lata Toxins}

The biological action of eutypine (1, Figure 2) in grapevines has been extensively studied [32]. Eutypine is synthesised by the fungus in the trunk and is thought to be transported by the sap to the herbaceous parts of the plant, where it spreads through the leaves and inflorescences to participate in the expression of disease symptoms [33]. Eutypine has weak acid properties and a marked lipophilic character. It penetrates the vine cells by passive diffusion and accumulates in the cytoplasm due to an ion-trapping mechanism related to the ionisation state of the compound [33]. In this case the experiments were carried out on the plasmalemma of three models: V. vinifera, Beta vulgaris and Minosa pudica. These biological models were suitable for particular physiological processes. The observations obtained from these studies showed that eutypine was unspecific since it indifferently acted on all three plant cell models used [33] (Table 1).

Table 1. Metabolites isolated from Eutypa lata and phytotoxicity assays.

\begin{tabular}{|c|c|c|}
\hline Metabolite (Figure 2) & Plant matrix used for phytotoxicity assays & References \\
\hline Eutypine (1) & $\begin{array}{l}\text { Grapevine leaves, tomato leaves, grapevine, } \\
\text { mimosa and sugar beet membranes, mitochondria }\end{array}$ & {$[26-28,31,33-35]$} \\
\hline Eutypinol (2) & Grapevine and tomato leaves & {$[26-28,31]$} \\
\hline$O$-Methyleutypine (3) & Grapevine and tomato leaves, mitochondria & {$[26,34-36]$} \\
\hline$O$-Methyleutypinol (4) & Grapevine leaves, tomato leaves & {$[26]$} \\
\hline Eutypin carboxylic acid anologue (5) & Grapevine leaves, tomato leaves & {$[26]$} \\
\hline 3-(3,4-Dihydroxy-3-methyl-1-butynyl)-4-hydroxy-benzaldehyde (6) & Grapevine leaves, tomato leaves & {$[26]$} \\
\hline 2-(3,4-Dihydroxy-3-methyl-1-butynyl)-4-hydroxymethyl-phenol (7) & Grapevine and tomato leaves & {$[26]$} \\
\hline 3-(3,4-Dihydroxy-3-methyl-1-butynyl)-4-hydroxy-benzoic acid (8) & Grapevine leaves, tomato leaves & {$[26]$} \\
\hline 2-iso-Propenyl-5-formylbenzofuran (9) & Grapevine and tomato leaves & {$[26,28,31]$} \\
\hline Siccayne (10) & Grapevine leaves & {$[28,31]$} \\
\hline Eulatinol (11) & Grapevine leaves & {$[28]$} \\
\hline Eulatachromene (12) & Grapevine leaves & {$[28,31]$} \\
\hline Epoxidised chromanones $(\mathbf{1 3}, \mathbf{1 4})$ & Grapevine leaves & {$[26]$} \\
\hline Eutypoxide B (15) & Grapevine leaves & [29] \\
\hline Allenic epoxycyclohexane (16) & Grapevine leaves & {$[29]$} \\
\hline
\end{tabular}

That eutypine targets the mitochondria is suggested by the fact that it modifies the rate of respiration of the grapevine cell and its energy balance [34-36].

The molecular mode of action of eutypine at the mitochondrial level, and of $O$-methyleutypine (3, Figure 2), the non-deprotonatable derivative of 1 (Figure 2), was investigated [34]. The effects of these molecules on mitochondrial respiration and on the membrane potential were compared using isolated mitochondria from grapevine cells in suspension cultures. Eutypine caused marked stimulation of oxygen consumption and had a depolarising effect, while methyleutypine had a very slight effect on both the rate of oxygen uptake and membrane potential. High eutypine concentrations had a mixed effect, with a direct inhibition of electron transport and uncoupling. At concentrations below $200 \mathrm{mM}$, eutypine displayed a linear relationship between the oxidation rate and the membrane potential, similar to that of the traditional protonophore carbonyl cyanide $m$-chlorophenylhydrazone (CCCP). But unlike $\mathrm{CCCP}$, eutypine induced a potential-dependent proton conductance, which was probably due to a 
potential-dependent migration of the dissociated form of the toxin across the membrane. It was thus concluded that eutypine uncouples mitochondrial oxidative phosphorylation and decreases the ADP/O ratio in grapevine cells by increasing proton leaks, which it accomplishes by means of a cyclic protonophore mechanism $[35,36]$.

A further study of five mutant strains of Saccharomyces cerevisiae showed that eutypinol and eulatachromene ( 2 and 12, Figure 2) inhibited mitochondrial respiration in wild-type yeast, and that 2-iso-prenyl-5-formyl-benzofuran and siccayne (9 and 10, Figure 2) inhibited respiration in the strain lacking in mitochondrial respiration and vacuolar acidification. These effects of eutypinol and eulatachromene were confirmed using a strain with mitochondrial dysfunction and hypersensitivity to oxidative stress [32]. This study was not conducted on grapevine cells (Table 1).

\subsection{Eutyta lata Toxins as Virulence Factors}

Eutypa lata toxins are non-specific and appear to be important virulence factors in causing the symptoms of Eutypa dieback [35]. However, a lack of toxin-deficient mutants of the fungus, as well as the long time the fungus needs to incubate in the trunk before symptoms appeared, prevented a much-needed critical study of these toxins in grapevine. Nevertheless, it was confirmed that eutypine in grapevine cells is metabolised into the corresponding alcohol, eutypinol (2, Figure 2), through the enzymatic reduction of eutypine by a NADPH-dependent enzyme [37,38]. Eutypinol was not toxic to grapevine and had no protonophoric activity. The high affinity of the eutypine reductase enzyme (ERE) for eutypine indicated that ERE may play an important role in the detoxification of eutypine. It was also found that eutypinol did not have any uncoupling activity in the mitochondria [39] unlike what was seen with $S$. cerevisiae [32]. When the detoxification of leaf tissue by two genotypes of $V$. vinifera is compared, there seems to be a relationship between the susceptibility of vine cultivars to Eutypa dieback and the degree to which these vines deactivate eutypine [40]. Novel NADPH-dependent aldehyde reductase genes conferring resistance to eutypine have been reported from Vigna radiata [40,41]. This suggests that detoxification enhances the resistance of the vines to the toxin [39].

\subsection{Analytical Detection of Eutypa lata Toxins in Vitro and in Planta}

Eutypa lata synthesises a variety of metabolites, whose role in causing dieback is quite unclear. This role needs to be elucidated before any attempt can be made to apply these metabolites in order to diagnose E. lata dieback. Some studies have been carried out to determine the best growing conditions for E. lata, and to optimise its production of toxic metabolites in an artificial environment, especially on grapevine wood and wood extracts. Molyneux et al. [27] studied in vitro variations in the metabolite production of three E. lata isolates, using two growth media [malt yeast broth (MYB) and potato dextrose broth (PDB)], and a longer term, than previously reported. These researchers examined three representative strains of $E$. lata, two from grapevine (E120 and E125), and one strain from oak in California, to serve as a representative non-grapevine host species (E178). Metabolite composition and yield differed significantly between strains and between growth media, but yield usually peaked after 24-30 days [27]. Metabolites were identified by gas chromatography/mass spectrometry of their trimethylsilyl ether derivatives and analysed. This method proved to be generally applicable to all the 
metabolites subsequently isolated, with the trimethylsilyl derivatives well resolved [27]. Eutypine, eutypinol, siccayene and eulatinol $(\mathbf{1}, \mathbf{2}, \mathbf{1 0}, \mathbf{1 1}$, Figure 2) were quantified by high-performance liquid chromatography (HPLC) in the three strains on MYB and PDB. Eutypine (1) was detected in only one of the strains (E125) on both media. The primary metabolite was the detoxification product eutypinol (2). This metabolite was produced in large quantities by one of the strains grown on PDB, but it was detected in all strains [18]. Strain E178 from oak did not produce these metabolites [27].

Subsequently, the HPLC procedure was optimised to establish the phenolic metabolite profiles of eleven E. lata strains grown on four growth media and to determine how the growth of these strains in these media differed from their growth on "Cabernet Sauvignon" vine wood and wood extracts [28]. The same technique was used to evaluate secondary metabolite production of 30 isolates of E. lata grown on media derived from the canes of three grapevine cultivars, two of which (Merlot and Semillom) were tolerant to E. lata, and one (Shiraz) susceptible [10]. Eutypine, eutypinol, $O$-methyl-eutypinol, 2-iso-propenyl-5-formylbenzofuran, eulatinol and eulatachromene (1, 2, 4, 9, 11 and 12, Figure 2) were detected in all culture filtrates. The most abundant metabolites were eutypinol and $O$-methyl-eutypinol, which were produced by 97 and $83 \%$ of isolates respectively. No correlation was found between secondary metabolite levels in the media containing ground canes from the three grapevine cultivars, and the tolerance/susceptibility of these cultivars to Eutypa dieback. In addition, no secondary metabolites of $E$. lata were detected from any isolates of other fungi commonly isolated from grapevine trunks in Australia such as Cryptovalsa ampelina, Libertella sp., Pa. chlamydospora, Pm. aleophilum, and various species of Botryosphaeriaceae and Fomitiporia that were grown on ground canes. This suggests that these metabolites are specific to E. lata [10]. To detect the secondary metabolites in planta, micropropagated grapevine plantlets were treated with purified and crude culture filtrates of nine $E$. lata isolates grown on MYB. The secondary metabolites 1, 2, 4, 9, 11 and 12 (Figure 2) were identified in some of the treated plantlets, but no single metabolite was detected consistently in all plantlets. Eutypinol was detected in micropropagated grapevine plantlets inoculated with E. lata mycelium; however, no metabolites were detected in the sap of plotted vines that had been mechanically inoculated with the pathogen [10].

As mentioned above, eutypinol is not toxic when applied to grapevine leaf disks $[19,23]$. However, this lack of toxicity does not preclude the use of this metabolite as a chemical marker, since the pathogenicity of E. lata is not due solely to the phenolic metabolites it produces, but also to the fact that it colonises grapevine wood and degrades the xylem. Consequently, whenever a non-toxic metabolite of E. lata such as eutypinol is detected in a vine, it is a positive indication of the occurrence of E. lata itself [28].

DNA-based markers to identify E. lata in infected vine wood have been developed $[42,43]$. Although identification techniques based on DNA analysis are sensitive enough, they are destructive and the particular vine portion sampled must actually contain E. lata; if healthy tissues from an infected vine are sampled, a false negative reading may result. However, the metabolites of E. lata are likely to be distributed throughout the vascular tissue and foliage of infected vines, especially in spring when the foliar symptoms are most evident. A diagnosis based on identifying such specific metabolites of E. lata in planta can therefore be carried out early in the season, even before the pathogen itself has spread throughout the vine. False negatives are in any case possible since foliar symptoms, and hence 
also toxin translocation, fluctuate from year to year on infected spurs or branches, as is common in leaf stripe disease [44].

\section{Esca, A Complex of Diseases}

The term esca complex was introduced at the end of the last century $[45,46]$ and has more recently been redefined. The esca complex is a complex of two diseases, which may co-occur in the same vine: a wood rot (also called esca, in its redefined sense), and a vascular disease [2,47-52]. The vascular disease in turn comprises three syndromes, all of which are caused by Pa. chlamydospora and Pm. aleophilum. Pm. aleophilum is by far the most common [2,52] of the twenty-four Phaeoacremonium species that have been isolated from both symptomatic and asymptomatic grapevine wood in different parts of the world $[7,48]$. The three vascular syndromes are: brown wood streaking, Petri disease, and grapevine leaf-stripe disease, previously known as young esca $[2,47]$. Brown wood streaking is an infection of pre-planting propagation material, and produces wood discolouration and necrosis of the vessels, occurring at a stage where the vine has not yet got any leaves. Petri disease is a decline occurring in young vineyards, in which some individual vines lose their vigour and exhibit weak growth, with thin stems and a faint aspecific chlorosis or marginal necrosis of the leaves [48-51]. These symptoms are more severe in grafted than in self-rooted cuttings. The internal symptoms of visibly declining vines but also of vines that are still asymptomatic, show up as brown-black streaking of the wood in cross-section (just like brown streaking in diseased vine cuttings). Streaks often form a black ring around the pith, or appear as scattered black dots [2,52]. The symptoms of leaf stripe disease are wood necrosis (but not wood rot), brown-red discolouration, and vascular necrosis or black streaking with black gummy exudates. These symptoms are linked to the typical foliar interveinal necrosis, were the leaf blade is necrotic and is surrounded by yellow or red margins, but the area immediately surrounding the main veins remains fully green, thus giving the leaf a typical tiger-stripe pattern (Figure 5).

In the Mediterranean area wood decay is caused almost exclusively by Fomitiporia mediterranea, while elsewhere it is caused by other basidiomycete species (other species of Fomitiporia, species of Fomitiporella, Inocutis and others) [1,3]. Symptoms are internal white decay or wood rot on artificially or naturally infected vines, but no association with any type of foliar symptom has been found.

Lastly, since two of the diseases of the esca complex, white decay and the vascular disease, are very often found on the same vine in the field, the term esca proper also denotes a vine (especially an older vine) affected with both these diseases.

The terms chronic (or mild) esca and acute esca should therefore be abandoned. The acute form of esca indicated an apoplexy or sudden death of a vine and appears to be related to white decay, while chronic esca referred to vines showing tiger like symptoms on the leaves, which is the equivalent of what is now termed leaf-stripe disease. 
Figure 5. (A) Vine leaf showing leaf stripe disease (previously young esca) and an affected grape cluster; (B) leaves showing the initial interveinal chlorotic spots; (C) black gummy material from Phaeomoniella chlamydospora infected wood, brown red wood and white decay caused by Fomitiporia mediterranea.

(A)
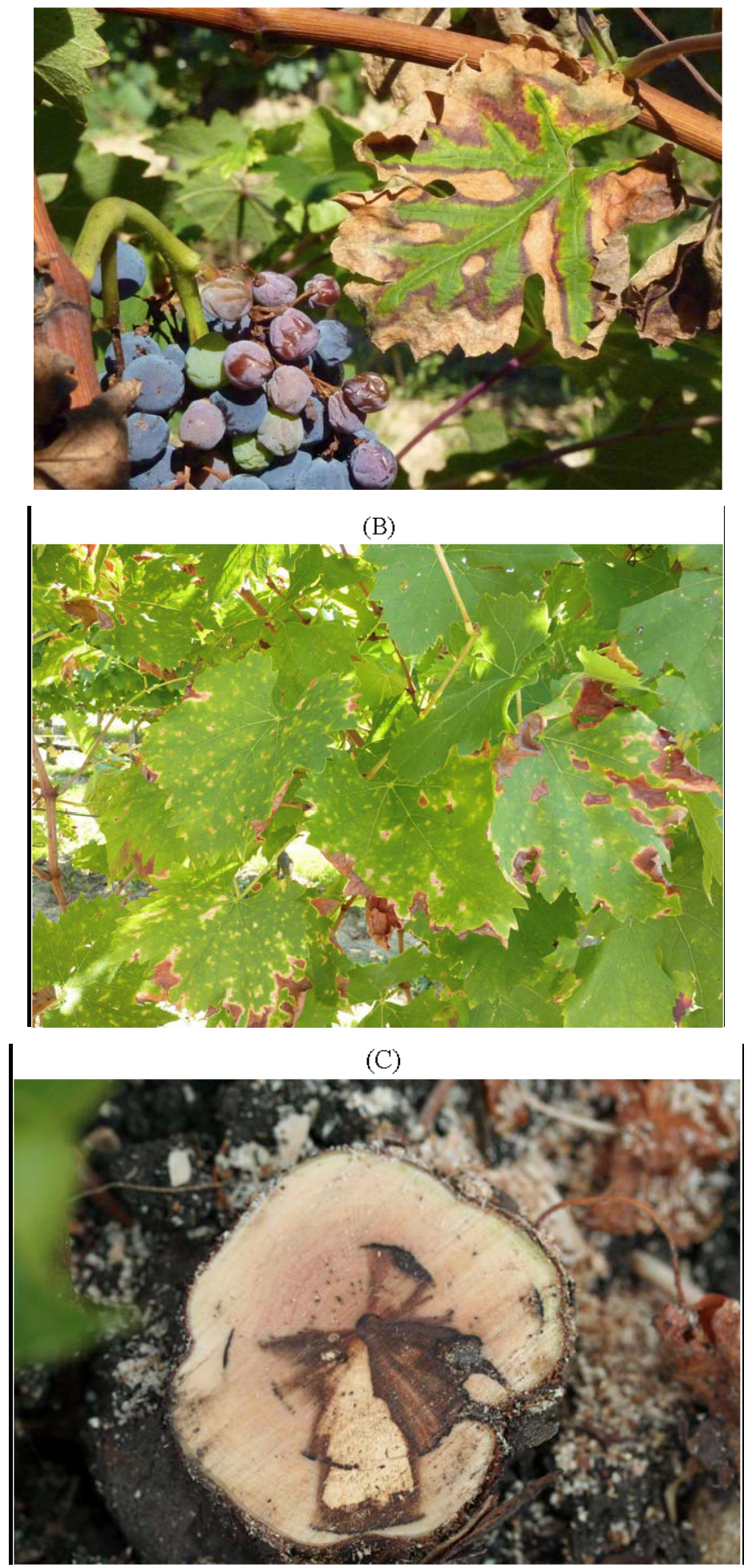

This complex of diseases causes serious losses especially in all European wine-growing countries and in the USA. While the leaf-stripe symptoms appear to be linked to the vascular disease, a sudden 
wilt (known as apoplexy) also occurs, which eventually leads to the death of the vine. Apoplexy occurs both in vines affected with the leaf-stripe symptoms and in vines with white rot which is itself the combined effect of on the one hand extensive wood deterioration caused by the rot fungi, and on the other hand certain toxins produced by Pa. chlamydospora and/or Pm. aleophilum [53]. The shoots, leaves, and berries also become affected (Figure 5).

To simplify the reading of this review, only the term esca will be used from now on to refer to the esca complex in general.

3.1. Toxins Produced by Phaeomoniella chlamydospora and Phaeoacremonium aleophilum, Main Causal Agents of Leaf Stripe Disease

\subsubsection{Lipophilic Low-Molecular Weight Metabolites}

Various metabolites, representing different classes of natural compounds, have been isolated and identified from culture filtrates of Pm. aleophilum and Pa. chlamydospora. They include naphthalenone pentaketides. From liquid culture of $P m$. aleophilum were isolated scytalone, isosclerone [54,55], cis-4-hydroxy-scytalone, 1,3,8-trihydroxynaphtalene $\quad(1,3,8$-THN), 2,4,8-trihydroxytetralone (2,4,8-THT), 3,4,8-trihydroxytetralone $\quad(3,4,8$-THT), flavioline, 2-hydroxyjuglone (2-HJ, traces), and 4-hydroxybenzaldehyde (20-28, Figure 6) [55]. Liquid cultures of $\mathrm{Pa}$. chlamydospora, have yielded, besides scytalone, isosclerone and 4-hydroxybenzaldehyde already mentioned (compounds 20, 21, 28, Figure 7) [55], also tyrosol, 1- $O$-methylemodine, 3-hydroxy-5-decanolide, $(S)$-4-hydroxyphenyllactic acid and 4-hydroxy-3-(3-methyl-2-butenyloxy)benzoic acid (29-33, Figure 7) [55].

Figure 6. Chemical structures of Phaeoacremonium aleophilum metabolites: scytalone, isosclerone, cis-4-hydroxyscytalone, 1,3,8-trihydroxynaphtalene, 2,4,8-trihydroxytetralone, 3,4,8-trihydroxytetralone, flavioline, 2-hydroyjuglone and 4-hydroxybenzaldehyde 20-28.

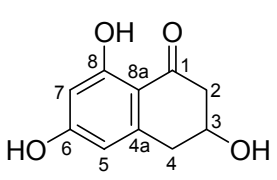

20<smiles>Oc1cc(O)c2cccc(O)c2c1</smiles>

23<smiles>O=C1C(O)=CC(=O)c2c(O)cc(O)cc21</smiles>

26<smiles>O=C1CCC(O)c2cccc(O)c21</smiles>

21<smiles>O=C1c2c(O)cccc2C(O)CC1O</smiles>

24

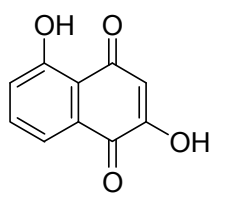

27<smiles>O=C1CC(O)C(O)c2cc(O)cc(O)c21</smiles><smiles>O=C1CC(O)C(O)c2cccc(O)c21</smiles>

25<smiles>O=Cc1ccc(O)cc1</smiles>

28 
Figure 7. Chemical structures of Phaeomoniella chlamydospora metabolites: scytalone, isosclerone (20-21), 4-hydroxybenzaldeide, tyrosol, 1-O-methylemodine, 3-hydroxy-5decanolide, (S)-4-hydroxyphenyllactic acid, 3-(3-methyl-2-butenyloxy)-4-hydroxybenzoic acid (28-33).<smiles>O=C1CC(O)Cc2cc(O)cc(O)c21</smiles>

20<smiles>O=C1CCC(O)c2cccc(O)c21</smiles>

21<smiles>O=Cc1ccc(O)cc1</smiles>

28<smiles>CCCCCC1CC(O)CC(=O)O1</smiles>

31<smiles>O=C(O)C(O)Cc1ccc(O)cc1</smiles>

32<smiles>COc1cc(C)cc2c1C(=O)c1c(O)cc(O)cc1C2=O</smiles>

30<smiles>CC(C)=CCOc1cc(C(=O)O)ccc1O</smiles>

33

The biological activity of metabolites produced by Pm. aleophilum and Pa. chlamydospora were evaluated against grapevine leaves, calli and living protoplasts (Table 2).

Table 2. Metabolites isolated from Phaeoacremonium aleophilum and Phaeomoniella chlamydospora and phytotoxicity assays.

\begin{tabular}{|c|c|c|}
\hline Metabolite (Figures 6 and 7) & Plant matrix used for phytotoxicity assays & References \\
\hline Scytalone (20) & $\begin{array}{l}\text { Grapevine leaves Grapevine callus and } \\
\text { protoplasts Arabidopsis thaliana }\end{array}$ & {$[54-57]$} \\
\hline Isosclerone (21) & $\begin{array}{l}\text { Grapevine leaves Grapevine callus and } \\
\text { protoplasts Arabidopsis thaliana }\end{array}$ & {$[54-57]$} \\
\hline cis-4-Hydroxyscytalone (22) & Grapevine callus and protoplasts & [57] \\
\hline $1,3,8$-Trihydroxynaphthalene $(1,3,8$-THN) (23) & Grapevine callus & [57] \\
\hline 2,4,8-Trihydroxy-tetralone $(2,4,8$-THT) (24) & Grapevine callus Arabidopsis thaliana & {$[57]$} \\
\hline $3,4,8$-Trihydroxytetralone $(3,4,8$-THT) (25) & Grapevine callus Arabidopsis thaliana & {$[57]$} \\
\hline Flavioline (26) & Grapevine callus Arabidopsis thaliana & {$[55]$} \\
\hline 2-Hydroyjuglone (27) & Grapevine callus & {$[57]$} \\
\hline 4-Hydroxybenzaldehyde (28) & Grapevine callus and protoplasts & {$[55,57]$} \\
\hline (S)-4-Hydroxy-phenyllatic acid (32) & Grapevine callus and protoplasts & {$[55]$} \\
\hline $\begin{array}{l}\text { 3-(3-Methyl-2-butenyloxy)-4- } \\
\text { hydroxybenzoic acid (33) }\end{array}$ & Grapevine callus and protoplasts & {$[55]$} \\
\hline
\end{tabular}

Other metabolite activities, usually related to the natural ageing of the leaves (loss of cell membrane semipermeability - causing ion leakage - and membrane-lipid peroxidase) were also examined. Scytalone (20, Figures 6 and 7) assayed at $0.05 \mathrm{mg} / \mathrm{mL}$ on grapevine cv. Italia leaves, produced spots 
that were light-green to chlorotic, round to irregular, and that became coalescent or remained spread out over the leaf blade (Figure 8A). Isosclerone (21, Figure 6 and 7), assayed at $0.1 \mathrm{mg} / \mathrm{mL}$, caused large yellowish spots that slowly became coalescent and necrotic, and that were followed by distortion and withering of the leaf lamina (Figure 8B) [54]. In a number of in vitro tests, leaf cultures from grapevine cv. Thompson absorbing 0.1 and $0.05 \mathrm{mg} / \mathrm{mL}$ solutions containing scytalone or isosclerone only showed some marginal browning, slightly stronger at the higher concentration [56]. Scytalone was tested for factors relating to leaf ageing, but no real effect was seen (scytalone caused higher peroxidation, but only in the first $30 \mathrm{~min}$ ). On the other hand both scytalone and isosclerone increased ion leakage, and when leaf disks were soaked in a scytalone solution at a concentration of $0.05 \mu \mathrm{g} / \mathrm{mL}$, membrane semipermeability was impaired.

Figure 8. Absorption of (A) $3 \mathrm{~mL}$ of $0.05 \mathrm{mg} \mathrm{mL}^{-1}$ scytalone and (B) $0.1 \mathrm{mg} \mathrm{mL} \mathrm{mL}^{-1}$ isoslerone by detached leaves of grapevine cv. Italia exposed to these solutions for a few hours .(Reproduced with permission from the authors of [54]).

(A)

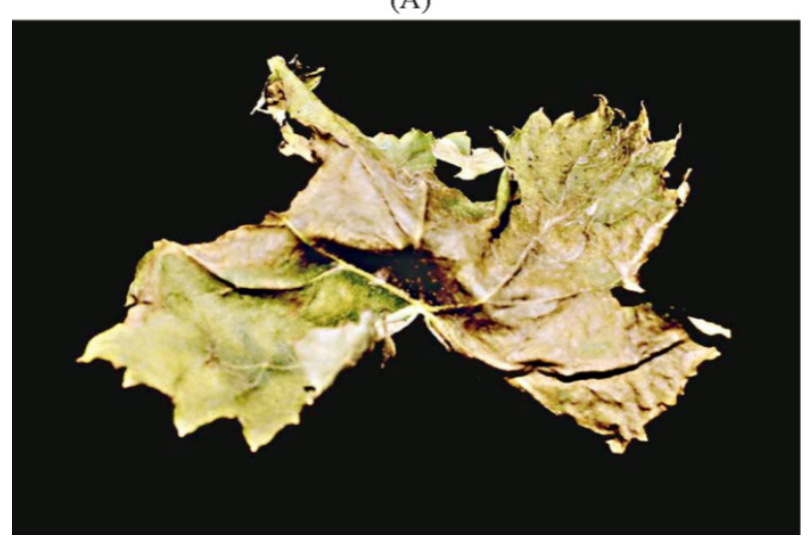

(B)

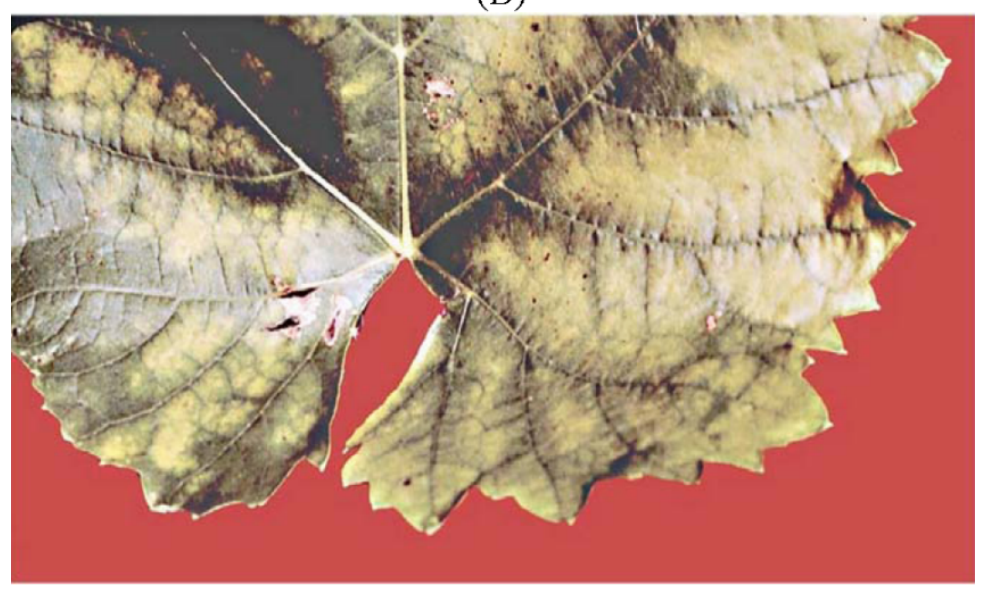

Scytalone and isosclerone (20-21, Figures 6 and 7) increased growth in vitro of calli of $V$. vinifera cv. Gamay at the lowest concentrations, 0.1 and $0.25 \mathrm{mM}$ respectively. Similar increases in callus growth were achieved with 3,4,8-THT (25, Figure 6) at $0.1 \mathrm{mM}$. On the other hand, the naphthoquinones such as juglone, 2-hydroxyjuglone (2-HJ) and 3-hydroxyjuglone (3-HJ) inhibited callus growth at $0.1 \mathrm{nM}$, and flaviolin (26, Figure 6) inhibited callus growth at $0.25 \mathrm{mM}$ [57]. These results differed slightly from the trials on calli from cv. Thompson and cv. Cabernet. When callus cultures from these cultivars were grown on a medium containing scytalone and isosclerone solutions at concentration 
increasing from 0.02 to 0.05 and $0.1 \mathrm{mg} / \mathrm{mL}$, the callus cultures became increasingly brown going from light brown to black; however, callus discolouration did not stop or reduce callus growth on either cv. Thompson seedless or cv. Cabernet [56].

The biological activity of 4-hydroxybenzaldehyde, $(S)$-4-hydroxyphenyllactic acid and 4-hydroxy3-(3-methyl-2-butenyloxy)-benzoic acid (28, 32-33, Figure 7) was determined on living protoplasts, from a hydroponic culture of Vitis vinifera cvs. Cabernet Sauvignon and Ugni blanc, by calculating the percentage of surviving protoplasts after growing them for $24 \mathrm{~h}$ together with the compounds at concentrations of from $10^{-5}$ to $10^{-6}$ M. 4-Hydroxybenzaldehyde (28, Figure 6 and 7) caused 20\% mortality of protoplasts at $100 \mathrm{nM}$ and $100 \%$ mortality at $1 \mathrm{mM}$. Metabolites 32 and 33 (Figure 7) were active on the protoplasts even at a concentration of $1 \mathrm{mM}$ [57] (Table 2).

\subsubsection{Hydrophilic High-Molecular Weight Metabolites}

\subsubsection{Polysaccharides}

When Pa. chlamydospora and Pm. aleophilum were grown in liquid culture, they produced exopolysaccharides (EPSs) in some tests [58]. In recent years, the structure of a large number of EPSs has been determined due to advances in ways to purify and chemically characterise these compounds [59].

That EPSs are involved in bacterial and fungal diseases has been reported by Hogdson et al. (1949); Harborne (1983) and Denny (1995) [60-61], but their activity as phytotoxins still remains to be clarified [62,63]. A number of phytopathogenic fungi produced EPSs toxic to plants. These fungi are Cephalosporium [64], Ceratocystis fagacearum [65], Ophiostoma ulmi [66], Fusarium solani [67], and several species of Phytophthora, including P. cinnamomi, P. megasperma var. sojae and P. palmivora, pathogens of forest, ornamental and agrarian plants such as oak, juniper and soybean [67]. Moreover, EPSs from the culture filtrates of $P$. cinnamomi, $P$. cryptogea and $P$. nicotianae cause severe wilting on several hosts [68]. It is thought that these macromolecules interfere with water movement in the plant tissues by plugging the vessels, and that this causes the wilt symptoms [69]. The wilting seems to be related to the size of the molecules and their viscosity rather than to their structure [70]. However some other experimental findings on host specificity suggest that the EPSs differently act. In fact, EPSs produced by some bacteria induced leaf spot diseases only on the host plants [71]. Furthermore, EPSs recently isolated from Cryphonectria parasitica [72], Phomopsis foeniculi [73] and Neofusicoccum parvum [74], were toxic to both hosts and non-host plants, and this suggests that they have non-specific phytoxicity.

Preliminary investigations, essentially using HPLC, molecular analysis and infrared spectroscopy, have revealed that $\mathrm{Pa}$. chlamydospora and $\mathrm{Pm}$. aleophilum produce pullulan [58]. Pullulan is a polysaccharide polymer consisting of maltotriose units, also known as $\alpha-(1 \rightarrow 4)-; \alpha-(1 \rightarrow 6)$-glucan. Three glucose units in maltotriose are connected by an $\alpha-(1 \rightarrow 4)$ - glycosidic bond, whereas consecutive maltotriose units are connected to each other by an $\alpha-(1 \rightarrow 6)$ glycosidic bond. Commercially pullulan is usually produced by the fungus Aureobasidium pullulans [75,76].

To establish the role of EPSs in esca, the EPSs were characterised biologically and their occurrence in infected vines was determined. It was found that when EPSs produced by Pm. aleophilum and $P a$. chlamydospora were absorbed at very low doses by detached grapevine leaves, or when they were 
injected into the woody tissue of the shoots and branches of standing grapevines, they caused foliar symptoms similar to those shown by vines with esca. The same symptoms were produced when the vine leaves were treated with pullulan extracted from the discoloured wood of a grapevine infected with $\mathrm{Pa}$. chlamydospora, and with commercial pullulan [58].

When culture filtrates of $P$ a chlamydospora, or weak solutions of purified preparations of scytalone, isosclerone or pullulan, were absorbed by detached leaves and berries they caused symptoms similar to those of vines affected with esca in the field [77].

\subsubsection{Polypeptide Toxic Metabolites}

Luini et al. [78] also reported on the toxic activity of polypeptides secreted by Pa. chlamydospora and Pm. aleophilum in their culture medium. The structures of these polypeptides have not yet been determined.

Even though the electrophoretic patterns of the polypeptides differed from those of the EPSs, their biological activity was very similar. They produced anthocyanins on grapevine leaves and, when applied to grapevine cells in culture, they modified proton fluxes, depolarised the cell membrane, inhibited the transport of sucrose and glutamine and, lastly, caused the death of the cells. Moreover, polypeptides can now be traced by immunological methods, as reported by Fleurat-Lessard et al. [79], and this has confirmed that these compounds have a significant role in the disease, and one that deserves further investigation.

\subsection{Toxins Produced by Fomitiporia mediterranea, a Causal Agent of Wood Rot in Grapevine.}

The toxic metabolites produced by $F$. mediterranea, the basidiomycetous fungus which, in Europe, is most frequently associated with grapevine white rot, were also investigated. Tabacchi et al. [55] reported that the culture filtrate of $F$. punctata (current nomenclature: $F$. mediterranea) produced 4-hydroxy-benzaldehyde (28, Figure 9), dihydroactinolide and a novel chromanone, called 6-formyl-2,2-dimethyl-4-chromanone, and biogenetically related to eutypine (34-35, Figure 9).

Figure 9. Chemical structures of Fomitiporia mediterranea metabolites: 4-hydroxybenzaldeide (28), dihydroactinolide (34) and 6-formyl-2,2-methyl-4-chromanone (35).<smiles>O=Cc1ccc(O)cc1</smiles>

28

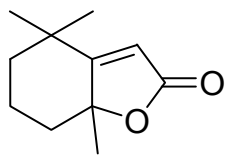

34<smiles>CC1(C)CC(=O)c2cc(C=O)ccc2O1</smiles>

35

White [80] reported that ten basidiomycetes isolated from grapevine in South Africa (8 novel species in the genera Fomitiporella, Fomitiporia, Inonotus, Inocutis, and Phellinus, and two species in an undetermined genus) produced in vitro 4-hydroxybenzaldehyde at fairly low concentrations ranging from 0.005 to $0.06 \mathrm{mg} / \mathrm{L}$. The level of 4-hydroxybenzaldehyde was not related to a specific taxon and varied within each taxon [80]. 


\subsection{Mechanism of Action of Toxins Involved in the Esca Complex (Vascular Disease and Wood Rot)}

The mode of action of the toxins, essentially naphthoquinones, produced by the fungi involved in esca may be related to their oxidant property. The quinones are extensively used in studies of oxidative stress because of the important role they play in plant defence [81]. Scytalone levels in particular may be related to the intensity of the brown-black colour of infected vine wood and to the occurrence of dark material in the xylem vessels.

Figure 10. The pentaketide pathway of melanin synthesis with flavioline and 2-hydroxyjuglone (2-HJ). 1,3,6,8-tetrahydroxynaphthalene (1,3,6,8-THN); 1,3,8-trihydroxynaphthalene $(1,3,8-\mathrm{THN}) ; 1,2,4,5,7$-pentahydroxynaphthalene (1,2,4,5,7-PHN); 5-hydroxyscytalone (5-HS); cis-4-hydroxyscytalone (4-HS); 1,2,4,5-tetrahydroxynaphthalene $(1,2,4,5-\mathrm{THN}) ; 3,4,8$-trihydroxytetralone $(3,4,8$-THT); 2,4,8-trihydroxytetralone $(2,4,8$-THT). (Reproduced with permission from the authors of [56])

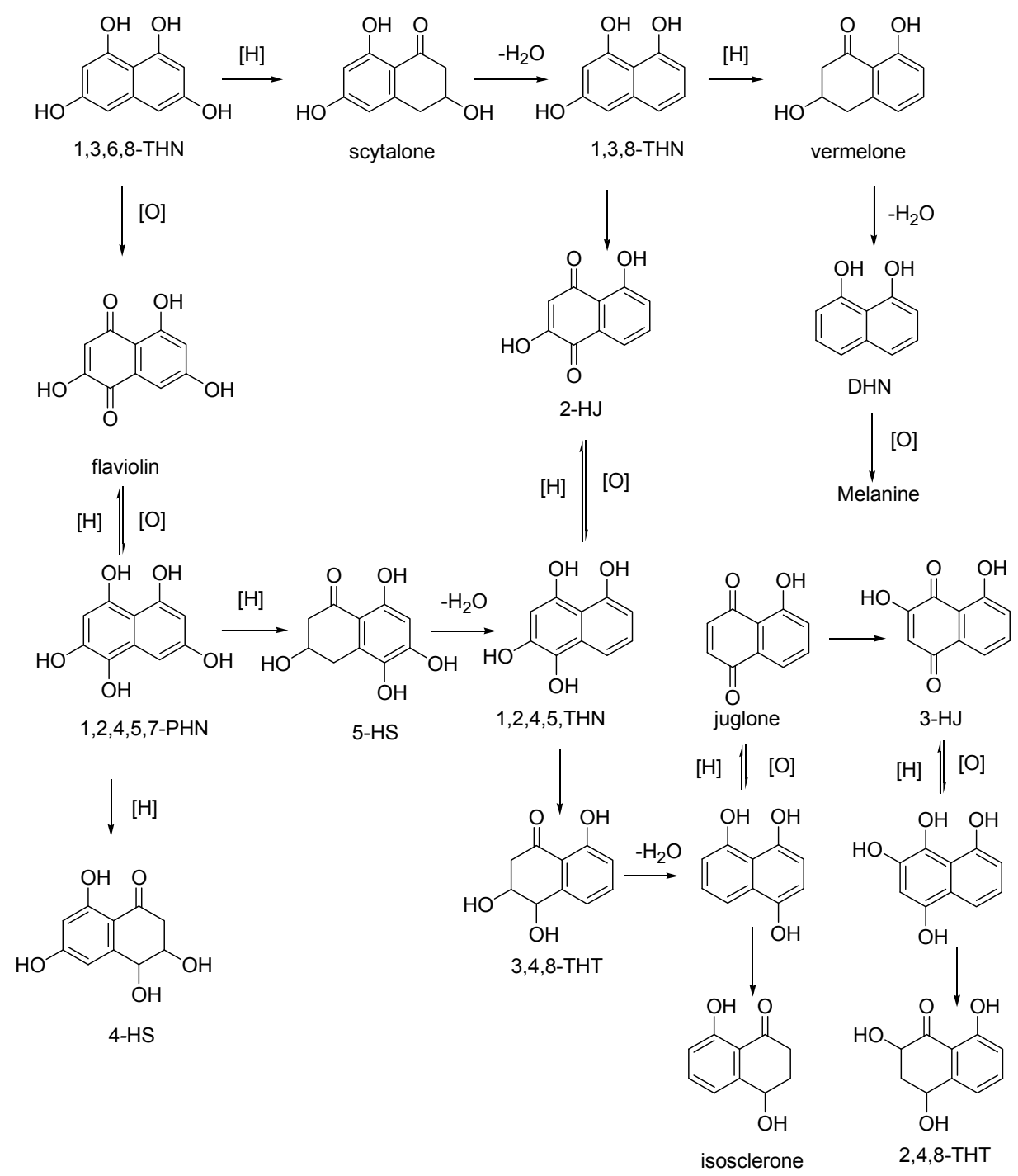

Scytalone and the naphthoquinones produced by Pa. chlamydospora and Pm. aleophilum are intermediate metabolites resulting from the biosyntesis of dihydroxynaphthale (DHN) melanins. Some studies examined the pentaketide pathway of melanin synthesis in some black fungi pathogenic to 
humans and plants $[82,83]$. As shown in Figure 10, scytalone may be produced by the oxidation of $1,3,8$-THN.

Melanins are dark pigments of a phenolic nature with a high molecular weight, which occur in animals, plants and micro-organisms. The structure of these pigments is unknown, and they probably are not necessary for the life of the producing organism, but they increase the capacity of that organism to survive under certain conditions. For example the occurrence of melanins in the cell wall of some fungi [84-86] increases the resistance of these fungi to physical agents such as UV radiation [86,87].

The role of melanins in virulence in may be due to various factors. Bürki et al. [88] reported that the naphthoquinones are cytotoxic, and they are thought to act by forming a covalent adduct through a Michael 1,4 addition between the quinone and a protein thiol or amino group [89]. Of these compounds, the most widely studied is juglone, which is highly toxic to plants and animals [61]. In fungal cells, juglone generates superoxide radicals, diminishing the cellular pool of reduced pyridine nucleotides which are particularly necessary for cells exposed to oxidative stress. It is well known that one of the main ways of plants to respond to phytopathogenic invasion is by generating $\mathrm{O}_{2}{ }^{-}$and $\mathrm{H}_{2} \mathrm{O}_{2}$ [90,91]. Many plants also produce auto-oxidisable quinone defence compounds, which oxidise NAD(P)H in plant and pathogenic cells, leading to the formation of superoxide radicals and hydrogen peroxide [92]. In response to these attempts of the plant to defend itself, the pathogenic fungi synthesise the naphthoquinones, which are toxic and suppress the defence reaction [93].

The naphthoquinones lower the resistance of plants to pathogenic fungi and hence enhance the virulence of those fungi. The production of naphthoquinone pigments appears to be an important component of the disease process as these pigments act as non-specific virulence factors inhibiting the plant defence reaction, resulting in plant hypersensitivity [94].

It has been reported that actively melanising cell-like appressoria of $P$. oryzae produce higher levels of melanin intermediates or their derivatives (phenols and quinones) in the presence of agents blocking melanin biosynthesis such as Tricyclazole ${ }^{\circledR}$ or Carpropamide ${ }^{\circledR}$ [95]. As phenols and quinones are highly toxic to living cells, an abnormal accumulation of metabolites such as 2-HJ probably prevents the appressoria from functioning [96].

Not much is known about how these metabolites act in the vine cells or tissues. The physiological changes that occur in the chlorotic portion of leaves with tiger-stripes, in the surrounding green portion of these leaves, and in the asymptomatic leaves of vine arms that also bear tiger-striped leaves, indirectly suggest that these changes are caused by toxic metabolites. Physiological changes include alterations in the rate of gas exchange, chlorophyll concentration, net photosynthesis, stomatic conductance, intercellular concentration of $\mathrm{CO}_{2}$, and transpiration rate [97,98]. Tiger-striped leaves also show higher levels of fructose and glucose and lower levels of sucrose. Starch goes down while abscissic acid goes up, as do the free amino-acids, especially proline [98,99]. The mechanism whereby these disorders are produced has not yet been elucidated, but the changes may be an indirect effect of the toxins produced by the fungi colonising the vine wood, and perhaps even by some non-pathogenic fungi which also abundantly colonise the vine wood. In that case these changes would be a response of the vine to the disease. For example, the increase of abcissic acid in the leaves, as also the increase in soluble sugars and amino-acids, appears to be a stress-response to an impairment of the conducting vessels [100]. 
Scytalone and isosclerone also cause peroxidation of the membrane lipids, and this is known to be related to leaf senescence [56]. Toxic polypeptides could also be involved in this early senescence process, since they cause an increase in the anthocyanin levels of vine leaves [78].

\subsection{Chemical and Immunological Detection of Esca-Related Metabolites}

As a rule, esca is first detected by visual inspection of the foliar symptoms. Visual inspection is completed by isolating on a growth medium the fungal colonies growing out of a piece of infected wood tissue and by identifying the growing fungus using microscopic inspection of the mycelium and the conidia, and/or by molecular methods.

A new means of detection is to employ HPLC or immunological techniques to identify the secondary metabolites secreted by the pathogen that is to be detected. Studies based on these techniques have established that secondary metabolites have a role as vivotoxins [101]

\subsubsection{HPLC Technique}

The role of fungal metabolites in causing symptoms on esca-affected vine leaves and berries was studied in a vineyard of $V$. vinifera cv. Italia located in southern Italy [102]. During early spring, two to four branches per vine were pruned and samples of xylem sap were collected. Vine bleeding, assessed as $\mathrm{mL}$ day ${ }^{-1}$ vine $^{-1}$, peaked at bud burst and stopped within 28 days. During this period, the leaf water potential of diseased vines progressively increased (i.e., values became less negative), indicating a dysfunction in the supply of water and nutrients to the new growth. Fungi were isolated both from the xylem sap and from the woody tissue of the branches and trunks of diseased vines. Conidia isolated from the sap showed a high germination rate $(>90 \%)$. Bioactive concentrations of the two pentaketides were detected in the xylem sap, leaves and berries at various stages of seasonal growth [58,103]. Exopolysaccharides, including pullulan, were found in the xylem sap.

\subsubsection{Immunological Techniques: Flow Cytometry}

A study has recently been carried out to develop a rapid and specific method for the production of polyclonal antibodies against the EPSs produced by Pa. chlamydospora and to detect these EPSs in the leaves of esca-affected grapevines [103]. The Pa. chlamydospora EPSs were unequivocally identified in diseased vines using flow cytometry. Antibodies raised against $\mathrm{Pa}$. chlamydospora EPSs were used as an antigen to immunise rats. Their specificity was also tested against other Pa. chlamydospora strains (Figure 11A). The antibodies did not recognise control EPSs from P. foeniculi or from P. exigua var. heteromorpha, nor EPSs from Pm. aleophilum, Neofusicoccum luteum or Neofusicoccum parvum, indicating that these antibodies were specific to the EPSs of $P a$. chlamydsopora [103]. Flow cytometry used in planta positively detected Pa. chlamydospora EPSs from esca-affected leaves showing interveinal and marginal discolouration, and necrosis (Figure 12) [103]. 
Figure 11. (A) Cytofluorimetric profiles of Phaeomoniella chlamydospora extracts from strains CBS 229.95, 7, 31, 135, 551 and 606. (B) Cytofluorimetric profile of leaf extracts of asymptomatic vine leaves from asymptomatic vine no. 61 (AAA) and from symptomatic vine no. 58. The position on the $\mathrm{x}$-axis clearly indicates no recognition by the antibodylabelled beads of the extracts from leaves from asymptomatic vines, and from asymptomatic leaves from asymptomatic shoots (ADD), not even when the leaves were close (ACD) or distal (AFD) to a symptomatic leaf in a symptomatic shoot (ADD). In contrast when the extracts of leaves with incipient chlorotic symptoms or leaves with fully developed symptoms from a diseased vine were tested (samples D and S, respectively), the position of the profiles on the $\mathrm{x}$-axis indicated there was strong recognition by the antibodies. Axis of abscissa is FL- $\log$ height; axis of ordinate is number of particles. (Reproduced with permission from the authors of [103]).
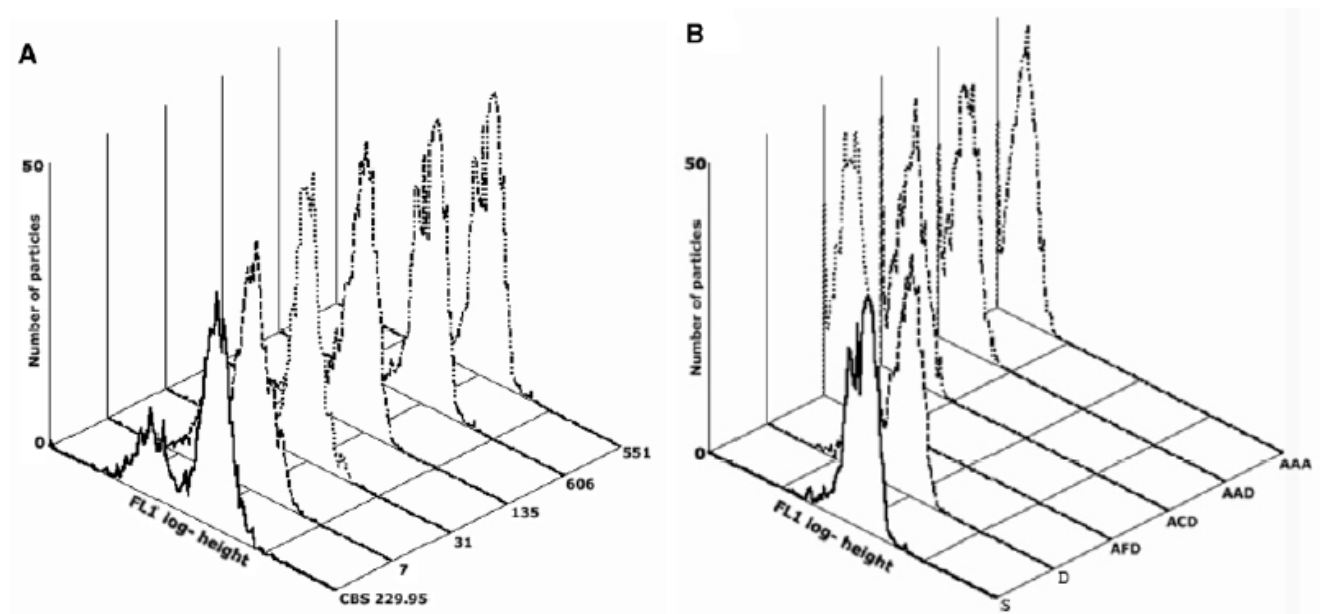

Figure 12. Esca-diseased grapevine leaves with tiger-stripe discoloration: a shoot showing the acropetal symptom gradient. (Reproduced with permission from the authors of [103])

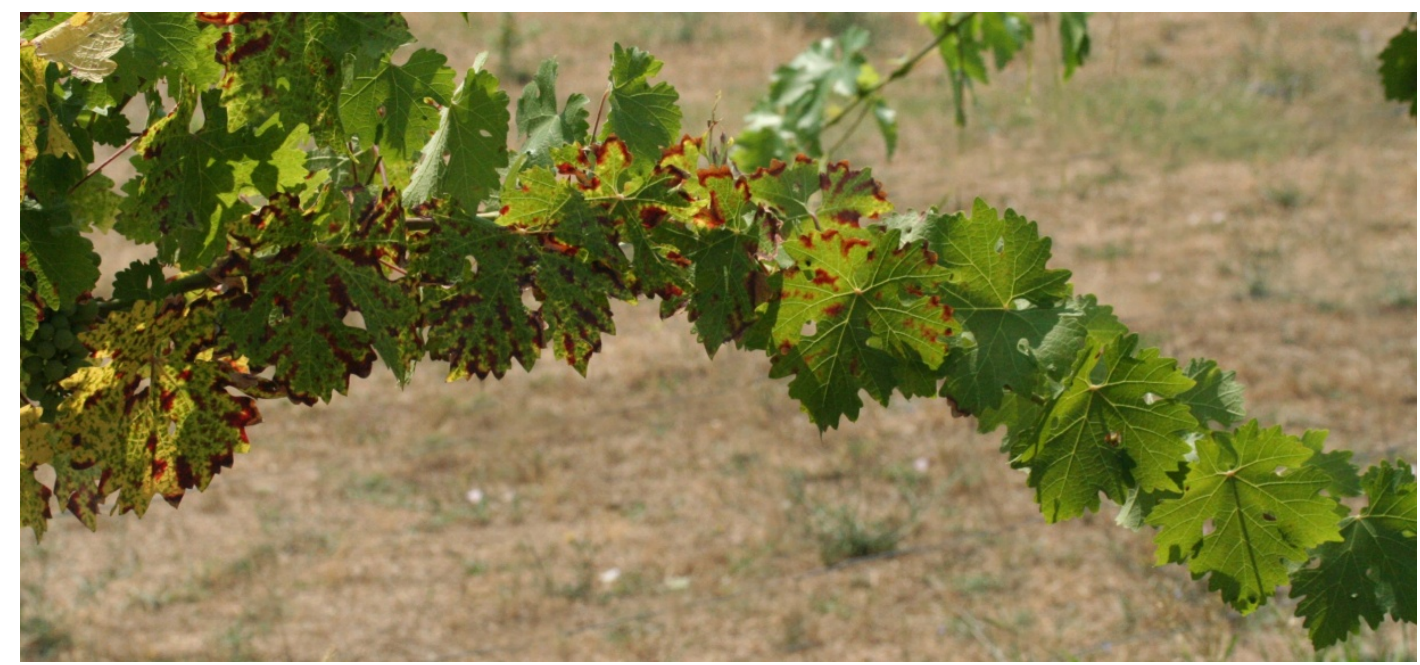

\subsubsection{Immunological Techniques: Serological Test}

Phaeomoniella chlamydospora in a culture medium secretes a variety of polypeptides [104,105], the biochemical nature of which made it possible to devise a serological test to detect them [79]. 
Polyclonal antibodies raised in rabbit against the polypeptide fraction produced by a $\mathrm{Pa}$. chlamydospora culture medium recognised small amounts of the secreted fungal proteins (commonly $1 \mathrm{ng}$ ). These antibodies had a valuable specificity because they cross-reacted with the polypeptides secreted by various strains of $\mathrm{Pa}$. chlamydospora but not with polypeptides secreted by any of the many other fungal pathogens commonly found in fungus-infected vine wood. Importantly, as shown by the enzyme-linked immunosorbent assay (ELISA) and by immunolocalisation on ultrathin sections, they did not cross-react with the polypeptides secreted by fungi causing other types of wood decay such as E. lata, or fungi causing cankers such as the Botryosphaeriaceae D. seriata and N. parvum. $P a$. chlamydospora was detected serologically in canes of mechanically infected cuttings [79]. The specificity of the antibodies was tested against fungal proteins from four strains of Pa. chlamydospora, since it is essential that the antibodies raised towards one strain should also be selective towards other strains of the same fungus. Western blot analysis confirmed that the antibodies directed towards the secreted proteins of strain PC-PC37 also recognised the other strains, although the response intensity differed between strains in some areas of the transferred bands (e.g., see the $98 \mathrm{kDa}$ bands). The global response measured by ELISA showed that the intensity of the reaction presented slight variations depending on the origin of the secreted antigen [79]. This made it possible to detect Pa. chlamydospora in grapevine with a dot blot method that was simple, rapid, reliable and non-destructive of the vines tested [79].

\subsection{NMR Metabolomics of Esca}

To study the metabolic changes in grapevine plants affected with esca, leaves were analysed from both symptomatic and non-symptomatic cordons of $V$. vinifera cv. Alvarinho, collected in the Vinho Verde region, Portugal. The metabolite composition of leaves from infected cordons with visible symptoms [diseased leaves (DL)] and from asymptomatic cordons [healthy leaves (HL)] was evaluated by $1 \mathrm{D}$ and $2 \mathrm{D}{ }^{1} \mathrm{H}$-nuclear magnetic resonance (NMR) spectroscopy [106].

Principal component analysis (PCA) of the NMR spectra showed a clear separation between DL and HL leaves, indicating that the compounds produced by these two types of leaves differed. NMR/PCA analysis identified the compounds belonging to each of the groups.

Altogether, levels of phenolic compounds were significantly higher in DL leaves than in HL leaves, and carbohydrate levels were significantly less, suggesting that the diseased leaves were rerouting carbon and energy from primary to secondary metabolism. The diseased leaves also had higher levels of methanol, alanine, and $\gamma$-aminobutyric acid, which may have been caused by the activation of other defence mechanisms [106]

\section{Botryosphaeriaceae Species Involved in Grapevine Trunk Diseases}

In recent years an increasing number of Botryosphaeriaceae species have been associated with grapevine decline worldwide $[6,107,108]$. Several diseases caused by these pathogens in grapevines are known, or have been known in the past, under a variety of names such as black dead arm (BDA), Botryosphaeria canker, excoriose, Diplodia cane dieback and bunch rot [6,109-112]. External symptoms of these diseases include death of the cordons, canes, shoots and buds, canker formation, stunting, delayed bud burst, bud necrosis, bleached canes, reduced bunch set and bunch rots, all of which have 
been extensively documented [6,109-116]. Internal symptoms on the trunks or canes of declining vines such as brown wood streaking and wedge-shaped discolourations are commonly associated with Botryosphaeriaceae species $[6,111-113,116]$. Some of the symptoms, both external and internal, are shown in Figure 13.

Figure 13. Symptoms of grapevine affected with various species of Botryosphaeriaceae. (A) Stunting early in the season; (B) Foliar chlorosis; (C) wedge-shaped necrosis in a trunk cross-section.

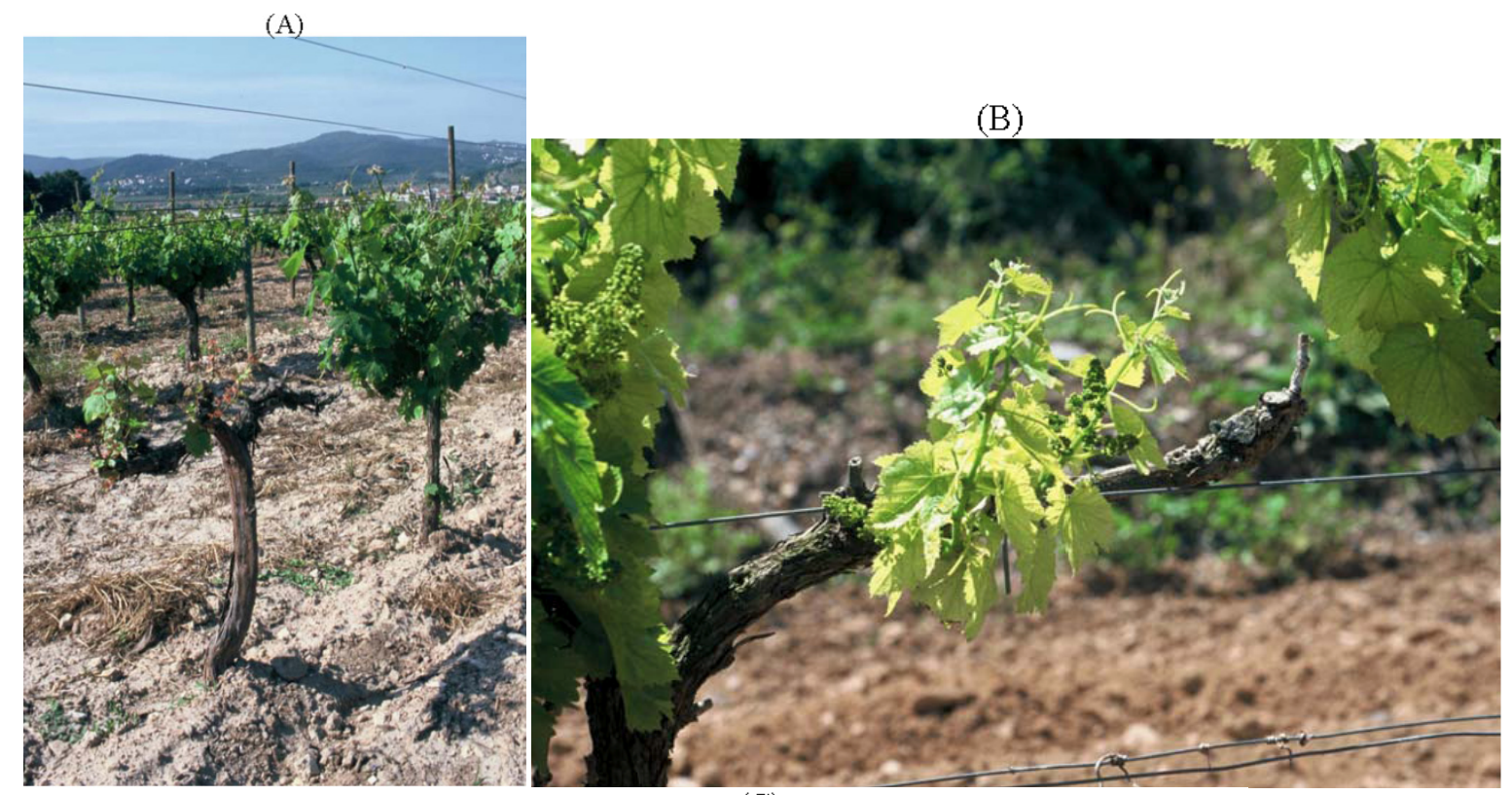

(C)

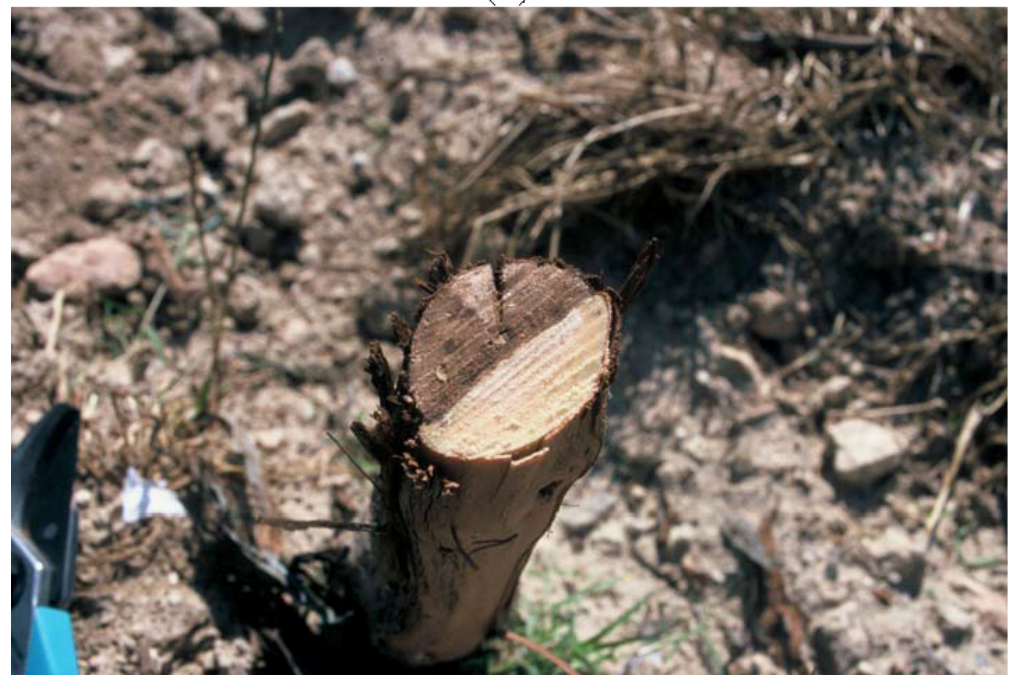

\subsection{Phytotoxic Metabolites from Botryosphaeriaceae Species}

Five species isolated from declining grapevines in Spain, Botryosphaeria dothidea, Diplodia seriata, Dothiorella viticola, Neofusicoccum luteum and $N$. parvum were examined for toxin production in liquid cultures of Czapek-Dox broth for different lengths of time [74]. All fungi produced high-molecular weight hydrophilic compounds with toxic properties (Figure 14). 
Figure 14. Toxic activity of organic extracts and related acqueous phases obtained from culture filtrates of Botryosphaeria dothidea, Diplodia seriata, Dothiorella viticola, Neofusicoccum luteum and N. parvum assayed on tomato plants. (Reproduced with permission from the authors of [74])

$\square$ B. dothidea $\square$ D. seriata $\square$ D. viticola $\square$ N. luteum 目 N. parvum

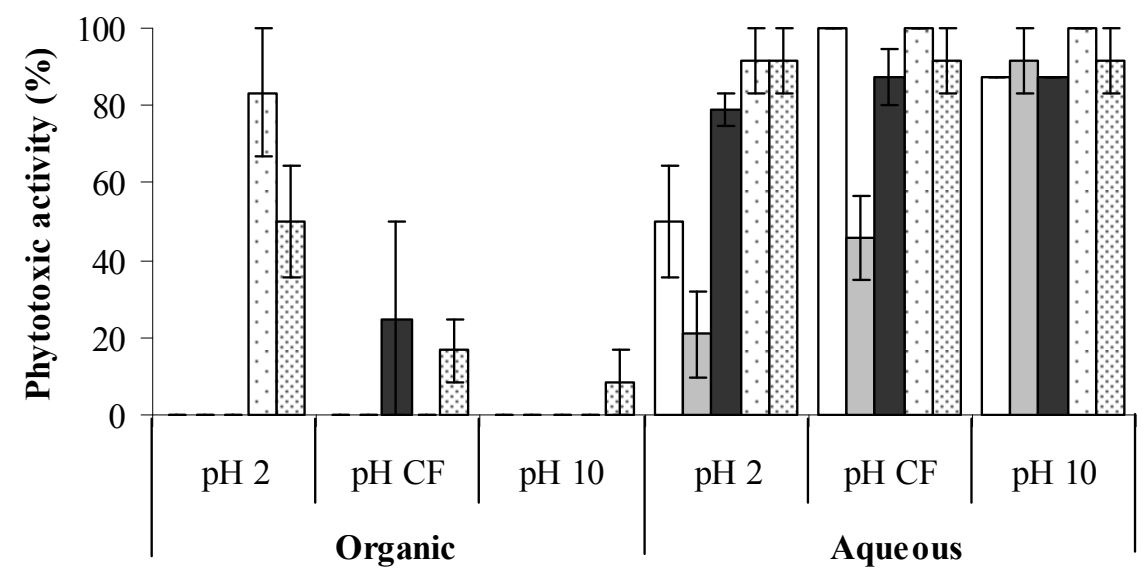

Toxin production of $D$. seriata and $N$. parvum peaked after 14 days in culture, while that of other species peaked after 21 days. The effect of 14 day-old $N$. parvum culture filtrate on grapevine leaves cv. Tempranillo is shown in Figure 15.

Figure 15. Symptoms caused on grapevine leaves of the cv. Tempranillo by 14-day-old culture filtrates of Neofusicoccum parvum: (A) severe withering; (B) partial withering with necrotic spots (arrows); (C) symptomless leaf (control immersed in distilled water). (Reproduced with permission from the authors of [74])
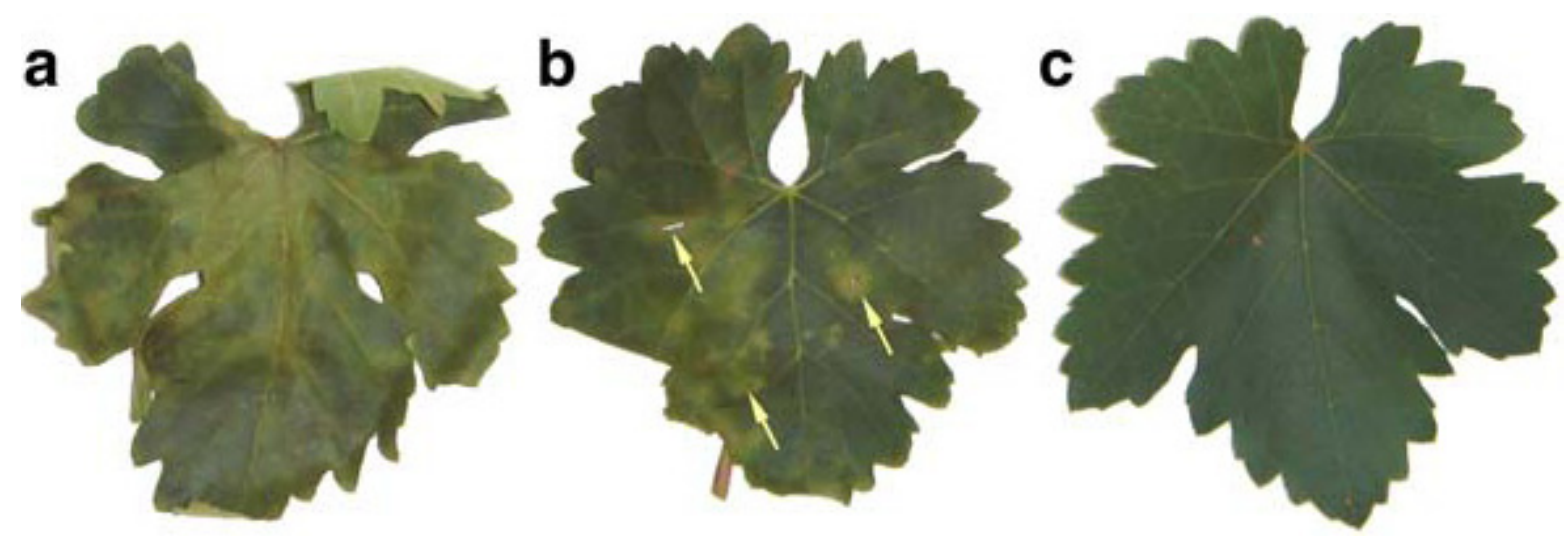

The high-molecular weight hydrophilic toxic compounds produced by $N$. parvum, which were later identified as EPSs, were further tested. GC-MS analysis of the acetylated $O$-methyl glycosides of these EPSs revealed that these compounds consisted mainly of glucose, mannose and galactose, and that they differed from the botryosphaerans [70]. The botryosphaerans are branched $\beta-(1 \rightarrow 3 ; 1 \rightarrow 6)$-D-glucans produced by B. rhodina [117] and by an unidentified ligninolytic Botryosphaeria sp. [70]. The role of EPSs in bacterial and fungal diseases has been revised in depth [118]. In addition, N. luteum and 
N. parvum produce low molecular weight lipophilic phytotoxins (Figure 14), that do not invariably occur in all the remaining species [74].

The sections following deal with the toxins produced by the most familiar Botryosphaeriaceae species associated with grapevine, $N$. parvum and D. seriata. However, further investigation, such as that into the toxins produced by other botryosphaeriaceous fungi and that into the toxic compounds of infected grapevines, is needed to better understand the role that these and other toxic compounds play in symptom expression.

\subsection{Toxins Produced by Neofusicoccum parvum}

In a recent study has isolated the metabolites produced by $N$. parvum (strain CBS 121486) in optimised culture condition and characterised them chemically and biologically [119]. Four toxic metabolites were isolated from the organic extract and identified by spectroscopic and physical examination as $(3 R, 4 R)-(-)-4$-hydroxy- and $(3 R, 4 S)-(-)-4$-hydroxy-mellein, isosclerone, and tyrosol $(36,37,21,29$, Figure 16), which were reported as being produced by N. parvum [119] for the first time.

When assayed on tomato cuttings all four metabolites (21, 29, 36, 37, Figure 16) were toxic, producing symptoms ranging from slight to severe leaf wilting (Table 3). (3R,4R)-(-)-4-hydroxymellein and isosclerone were the most toxic. All these toxins have already been reported as being produced by many phytopathogenic fungi [54,120-127].

Moreover, isosclerone (21, Figure 16) was reported for the first time as produced by a Botryosphaeriaceae species [119]. (3R,4R)-(-)-4-hydroxymellein (36, Figure 16) is produced, together with other melleins and tyrosol (29, Figure 16), by a strain of B. obtusa (syn. D. seriata) that causes frogeye leaf spot and black rot of apple [125,128]. The same 4-hydroxymellein as well as its steroisomer $(3 R, 4 S)-(-)-4-h y d r o x y m e l l e i n$ and mellein are also produced by Diplodia pinea (Desm.) Kickx, another Botryosphaeriaceae species, which causes decline of Pinus radiata D. Don in Sardinia, Italy [127].

Figure 16. Structures of $(3 R, 4 R)-(-)-4$-hydroxymellein, $(3 R, 4 S)-(-)-4$-hydroxymellein, isosclerone and tyrosol $(\mathbf{3 6}, \mathbf{3 7}, \mathbf{2 1}, \mathbf{2 9})$.<smiles>[R]C1([R2])c2cccc(O)c2C(=O)O[C@H]1C</smiles>

$36 \mathrm{R}_{1}=\mathrm{H}, \mathrm{R}_{2}=\mathrm{OH}$ $37 \mathrm{R}_{1}=\mathrm{OH}, \mathrm{R}_{2}=\mathrm{H}$<smiles>O=C1CCC(O)c2cccc(O)c21</smiles>

21<smiles>OCc1ccc(O)cc1</smiles> 
Table 3. Metabolites isolated from Neofusicoccum parvum and their toxicity assayed on tomato plants. (Reproduced with permission from the authors of [118])

\begin{tabular}{|c|c|c|c|c|c|}
\hline \multirow{2}{*}{ Metabolite } & \multirow{2}{*}{$\begin{array}{c}\text { Concentration } \\
(\mathrm{M}) \\
\end{array}$} & \multicolumn{3}{|c|}{ Toxicity rating ${ }^{a}$} & \multirow{2}{*}{$\begin{array}{l}\text { Mean toxicity } \\
\text { rating } \pm \text { S.E. }\end{array}$} \\
\hline & & Rep 1 & Rep 2 & Rep 3 & \\
\hline \multirow{3}{*}{$(3 R, 4 R)-(-)-4-H y d r o x y m e l l e i n(36)$} & $0.26 \times 10^{-3}$ & 2 & 2 & 3 & $2.3 \pm 0.33$ \\
\hline & $0.13 \times 10^{-3}$ & 1 & 1 & 3 & $1.7 \pm 0.67$ \\
\hline & $0.26 \times 10^{-4}$ & 1 & 1 & 2 & $1.3 \pm 0.33$ \\
\hline \multirow{3}{*}{$(3 R, 4 S)-(-)-4$-Hydroxymellein $(37)$} & $0.26 \times 10^{-3}$ & 0 & 1 & 2 & $1.0 \pm 0.58$ \\
\hline & $0.13 \times 10^{-3}$ & 0 & 1 & 1 & $0.7 \pm 0.33$ \\
\hline & $0.26 \times 10^{-4}$ & 0 & 1 & 0 & $0.3 \pm 0.33$ \\
\hline Isosclerone (21) & $0.31 \times 10^{-3}$ & 2 & 3 & 1 & $2.0 \pm 0.57$ \\
\hline Tyrosol (29) & $1.60 \times 10^{-3}$ & 2 & 2 & 1 & $1.7 \pm 0.33$ \\
\hline Control/Czapek-Dox & & 0 & 0 & 0 & $0.0 \pm 0.00$ \\
\hline Control/ $\mathrm{H}_{2} \mathrm{O}$ & & 0 & 1 & 0 & $0.3 \pm 0.33$ \\
\hline
\end{tabular}

${ }^{a}$ Lesion symptoms were evaluated using a 0-3 scale: (0) no symptoms; (1) slight wilting in one leaf; (2) moderate wilting on some leaves; (3) severe wilting on leaves (with necrotic spots on leaves occurring occasionally). Three plants (Rep 1 to Rep 3) were used for each sample tested.

Botryosphaeriaceae species were reported by Larignon et al. [95] to cause foliar symptoms (i.e., tiger-striped chlorosis and necrosis) but these cannot be clearly distinguished from the symptoms of grapevine leaf stripe (previously young esca). Those symptoms were described as belonging to a disease called black dead arm (BDA) which was attributed to several species of Botryosphaeriaceae. The difficulty encountered in distinguishing between different diseases having basically the same symptoms has been commented on by several authors [5,53,129]. Since isosclerone (21, Figure 16) and EPS are both produced by esca-associated fungi such as Pa. chlamydospora, Pm. aleophilum [54,55,58], $N$. parvum [74,119], and possibly other Botryosphaeriaceae species as well, it is necessary to clarify whether these toxins are related to the foliar symptoms of leaf stripe disease (young esca) or to BDA, if this disease is confirmed. If the symptoms cannot be distinguished, it would explain the confusion about how to diagnose these diseases if the diagnosis is based solely on the foliar symptoms. Although the cause of the chloro-necrotic foliar symptoms of esca still needs to be fully elucidated [5], it is possible to hypothesise that the foliar symptoms are the result of the synergistic action of the toxic metabolites produced by these pathogens, all of which colonise grapevine.

While isosclerone is produced by both the pathogenic botryosphaeriaceous fungi and the fungi causing esca, the melleins and their derivatives appear to be produced only by the botryosphaeriaceous fungi $[125,127,130]$. Tyrosol (29, Figure 16) is another toxic metabolite produced by plants and fungi, including B. obtusa $[123,125,131]$.

The fact that $N$. parvum produce isosclerone and exopolysaccharides is very interesting not only because these compounds are also produced by Pa. chlamydospora but because they are also involved in causing foliar symptoms of young esca and grapevine leaf-stripe disease [58,103]. Although the exact cause of these chloro-necrotic foliar symptoms is still unclear [5], they could be the result, wholly or in part, of the synergistic action of the toxic metabolites produced by species of Botryosphaeriaceae and Pa. chlamydospora [132]. 


\subsection{Toxins Produced by Diplodia Seriata}

Diplodia seriata (teleomorph: Botryosphaeria obtusa) is frequently associated with wood cankers of grapevine, sometimes named black dead arm or BDA [112,133], although this disease was initially reported by Lehoczky [134] as being caused not by D. seriata but by D. mutila. D. seriata also causes black rot of apple fruit, and produces several phenolic dihydroisocoumarins, such as mellein, cis-(3R,4R)-4-hydroxymellin and 5-hydroxymellein [125,128]. However, Djoukeng et al. [130] identified four phytotoxic compounds from a culture filtrate of $D$. seriata strain F-99-2, isolated from the vine cv. Cabernet Sauvignon. From an organic extract of the culture filtrates they isolated three known melleins, which on the basis of their spectroscopic data were identified as mellein, $(3 R, 4 R)$-4-hydroxymellein, (3R)-7-hydroxymellein and $(3 R, 4 R)-4,7$-dihydroxymellein $(\mathbf{3 8}, \mathbf{3 6}$ and $\mathbf{3 9}$, Figure 17). Using the same technique they further isolated a unknown mellein, characterised as $(3 R, 4 R)-4,7$-dihydroxymellein (40, Figure 17). A bioassay of vine cv. Gamay leaves found that $(3 R, 4 R)-4,7$-dihydroxy-mellein was the most active metabolite, causing full leaf necrosis with a minimum inhibitory concentration (MIC) of $2 \mu \mathrm{g} \mathrm{mL}{ }^{-1}$, although compounds $\mathbf{3 6}, \mathbf{3 8}$, and 39 (Figure 17) had a similar degree of toxicity with a MIC of $3 \mu \mathrm{g} \mathrm{mL}^{-1}$ [130]. These authors using a HPLC DAD-MS analysis found that mellein (38, Figure 17) also occurred in infected vine wood inoculated with $D$. seriata. In that case, mellein would be a good diagnostic marker for $D$. seriata in diseased vines, and could be used to differentiate between esca and BDA at an early stage, since the melleins and their derivatives are not produced by esca-associated pathogens such as Pa. chlamydospora, Pm. aleophilum or F. mediterranea [130]. Mellein and its derivatives are also produced by many other non-botryosphaeriaceous fungi, including the genera Aspergillus, Cercospora, Cryptosporiopsis, Hypoxylon, Phoma, Pezicula, Plectophomella, Septoria and Xylaria, and they have phytotoxic, zootoxic and moderate antifungal activities [124,127].

Figure 17. Structures of mellein, of $(3 R, 4 R)-(-)-4$-hydroxymellein, of (3R)-7-hydroxymellein and of $(3 R, 4 R)$-cis-4,7-dihydroxymellein $(\mathbf{3 8}, \mathbf{3 6}, 39, \mathbf{4 0})$, produced by Botryosphaeria obtusa.<smiles>[R2]c1ccc2c(c1O)C(=O)O[C@H](C)[C@H]2[R17]</smiles>

$$
\begin{aligned}
& 38 \mathrm{R}_{1}=\mathrm{H}, \mathrm{R}_{2}=\mathrm{H} \\
& \text { 36 } \mathrm{R}_{1}=\mathrm{OH}, \mathrm{R}_{2}=\mathrm{H} \\
& \text { 39 } \mathrm{R}_{1}=\mathrm{H}, \mathrm{R}_{2}=\mathrm{OH} \\
& 40 \mathrm{R}_{1}=\mathrm{OH}, \mathrm{R}_{2}=\mathrm{OH}
\end{aligned}
$$

As regards other toxins of $D$. seriata, it has been reported that tyrosol and $p$-hydroxybenzaldehyde were also produced by this pathogen, but only from an isolate obtained from apple [125,128]. Recently tyrosol has further been detected from $N$. parvum [119], and it cannot be excluded that some day D. seriata isolates will also be found to produce this toxin. 


\section{Grouping in Different Chemical Families of Phytoxins Produced by Different Fungi}

Frequently fungi produced toxins belonging to different classes of natural compounds and some of them are also produced by other fungi. However, a single toxin could be synthesized by one species and it would represents a taxonomical mark. A breakdown of the fungi and the toxins they produce is as follows:

Pm. aleophilum produces naphthalenone pentaketides and polyphenols; Pa. chlamydospora: naphthalenone pentaketides, polyphenols and anthraquinones; E. lata: acetylenic polyphenols, heterocyclic analogues and dihydro- $\gamma$-pyrones; and the Botryosphaeria species: naphthalenone pentaketides, melleins and polyphenols.

In these groupings the naphthalenone pentaketides and polyphenols are common to Pm. aleophilum, $P a$. chlamydospora and Botryosphaeria species. Toxins produced (among others) by only one fungus, and which may serve to detect that fungus, are: the anthraquinones, found only in Pa. chlamydospora, the acetylenic phenols and dihydro- $\gamma$-pyrones, both specific to E. lata, and the melleins exclusive to the Botryosphaeriaceous species.

\section{Conclusions}

Of the several diseases affecting grapevine, trunk diseases caused by fungi are important since they cause devastating epidemics and also considerable annual yield losses. Studies on toxins produced by grapevine trunk pathogens have become more frequent in the last two decades, and one of the findings has been that most of these pathogens produce secondary metabolites that are toxic to plants.

These phytotoxic substances have been at least in part chemically characterised, but their mode of action remains mostly to be elucidated. They have not yet been made the subject of particular study, except for eutypine, eutypinol, eulatinol and other metabolites produced by E. lata [32-35,38]. The toxicity of $E$. lata is probably due to a number of metabolites that are structurally related, each having a different level of toxicity and different molecular targets within the vine cell [32]. Of the toxins produced by the other trunk pathogens we know little that is significant (something is known only about the action of the naphthalenones, whose toxicity is thought to be linked to their oxidant properties).

All the bioactive substances produced by $P a$. chlamydospora, Pm. aleophilum, and the botryosphaeriaceous species were toxic to vines and other plants in toxicity tests on the leaves, calli or protoplasts of the host plants; when tested on the leaves of healthy plants at least some of these substances reproduced to a certain extent the original symptoms of the disease they caused $[24,33,55,56,58,60,74,78]$. These findings, though significant, are not generally thought to be sufficient to prove that these substances have a role in the diseases caused by the fungal pathogens; for now, such a conclusion would be mere speculation.

Some phytotoxic metabolites, such as the EPSs, the naphtalenone pentaketides and the polyphenols are common to more than one fungus, whereas other metabolites (the anthraquinones, the acetylenic polyphenols and dihydro- $\gamma$-pyrones and the mulleins) are specific to an individual fungus. Since the main pathogens examined in this review produce both localised symptoms in the wood and also in some cases symptoms on the leaves, it can be hypothesised that the metabolites first act at the place in the wood where they are produced, causing darkening of the tissues, necrosis of the parenchyma cells 
surrounding the vessels, exudation of dark gum into the vessels, and occlusion of the xylem vessels, and that subsequently some of these metabolites also act at a distance from the place of production, since they accumulate in the leaves.

As regards the leaves, it has been mentioned that in vines affected with grapevine leaf stripe (one of the vascular syndromes in the esca complex), significant physiological changes take place in both the chlorotic portion and the surrounding green portion of the leaves with tiger-stripes, and even in the (still) asymptomatic leaves of those vine arms that also bear tiger-striped leaves. These physiological changes mainly impair photosynthesis, so that it seems reasonable to assume that one or more of the metabolites, including the EPSs, act directly or indirectly on the plant metabolism and on the functionality of the chloroplasts. As for the mode of action of EPSs, it has been hypothesised that their main effect is to plug the xylem vessels, but, since the EPSs also accumulate in the leaf mesophyll, a direct effect of these macromolecules on the chloroplasts cannot be excluded, either by the EPSs in their original form, or after they have been partially degraded, a process which reduces their molecular weight but increases their mobility.

As stated above, the chlorosis and necrosis of esca-affected leaves can also be interpreted as a premature senescence resulting, at least in part, from the peroxidation of the membrane lipids [56], as shown by the increase in anthocyanin levels caused by the toxic polypeptides produced by $P a$. chlamydospora [78]. An increase in the anthocyanin levels of vine leaves is also a first stage in the formation of tiger stripes, and it is clear that the fully formed leaf stripe symptoms resemble senescent leaves about to fall.

Toxin levels and the rate of increase of these levels in the leaves may also explain some other characteristics of grapevine trunk diseases, particularly why leaf symptoms vary over time and over space. It is well known that vines affected with esca do not all begin to show foliar symptoms at the same time in a growing season. Foliar symptoms generally appear in June-July, but they can also appear in May, or in August-September, and in some infected vines they do not appear at all, or not on all leaves, for one or even more growing seasons. With these infected but temporarily asymptomatic vines it is not possible to predict in what growing season any of these vines, or any portion of their vine crown, will again begin to show leaf symptoms. E. lata dieback and Botryosphaeriaceae species share some of the same peculiarities. While all biological phenomena are naturally subjected to variation, it seems that with these diseases, at least some of the reactions recorded were due to the type and the particular mixture of the toxins that accumulated in the leaves, and this in turn was partly the result of the physiological status of the vine and the environmental conditions.

As regards the basidiomycetes, common agents of wood rot in grapevine ( $F$. mediterranea in Europe and the Mediterranean area; other basidiomycetes in other vine growing areas), the main virulence factors of these fungi consist in their degrading enzymes. However, recent studies have shown that these fungi also produce toxic metabolites in vitro. The role of these toxins in planta during symptom development remains to be elucidated [80].

In conclusion, some of the studies discussed in this review suggest that toxic metabolites have a notable role in causing the symptoms of grapevine trunk diseases. However, the exact mode of operation of these toxins, and the way in which they contribute, individually or jointly, to the expression of symptoms, is still not well understood. Further research is needed to elucidate the interaction 
between the phytotoxins and other abiotic factors which are involved in disease development, such as rainfall and the temperature regime $[44,135]$.

\section{References}

1. Carter, M.V. The Status of Eutypa Lata as a Pathogen; Phytopathological Paper No. 32; CAB International: Wallingford, Oxon, UK, 1991.

2. Mugnai, L.; Graniti, A.; Surico, G. Esca (black measles) and brown wood-streaking: Two old and elusive diseases of grapevines. Plant Dis. 1999, 83, 404-418.

3. Fischer, M. Biodiversity and geographic distribution of basidiomycetes causing esca-associated white rot in grapevine: A worldwide perspective. Phytopathol. Mediterr. 2006, 45, S30-S42.

4. Halleen, F.; Fourie, P.H.; Crous, P.W. A review of black foot disease of grapevine. Phytopathol. Mediterr. 2006, 45, S55-S67.

5. Surico, G.; Mugnai, L.; Marchi, G. Older and more recent observations on esca: A critical overview. Phytopathol. Mediterr. 2006, 45, S68-S86.

6. Van Niekerk, J.M.; Fourie, P.H.; Halleen, F.; Crous, P.W. Botryosphaeria spp. as grapevine trunk pathogens. Phytopathol. Mediterr. 2006, 45, S43-S54.

7. Mostert, L.; Halleen, F.; Fourie, P.; Crous, P.W. A review of Phaeoacremonium species involved in Petri disease and esca of grapevines. Phytopathol. Mediterr. 2006, 45, S12-S29.

8. Trouillas, F.P.; Gubler, W.D. Pathogenicity of Diatrypaceae species in grapevines in California. Plant Dis. 2010, 94, 867-872.

9. Trouillas, F.P.; Úrbez-Torres, J.R.; Gubler, W.D. Diversity of diatrypaceous fungi associated with grapevine canker diseases in California. Mycologia 2010, 102, 319-336.

10. Lardner, R.; Mahoney, N.; Zanker, T.P.; Molyneux, R.J.; Scott, E.S. Secondary metabolite production by the fungal pathogen Eutypa lata: Analysis of the extracts from grapevine cultures and detection of those metabolites in planta. Aust. J. Grape Wine Res. 2006, 12, 107-114.

11. Halleen, F.; Mostert, L.; Crous, P.W. Pathogenicity testing of lesser-known vascular fungi of grapevines. Australas. Plant Pathol. 2007, 36, 277-285.

12. Gramaje, D.; Mostert, L.; Armengol, J. Characterization of Cadophora luteo-olivacea and C. melinii isolates obtained from grapevines and environmental samples from grapevine nurseries in Spain. Phytopathol. Mediterr. 2011, 50, S112-S126.

13. Sosnowski, M.R.; Wicks, T.W.; Scott, E.S. Control of Eutypa dieback in grapevines using remedial surgery Phytopathol. Mediterr. 2011, 50, S277-S284.

14. Herche, R. Control Strategies for Trunk Diseases of Grapevine (Vitis vinifera L.). M.Agr. Thesis, University of California-Davis, CA, USA, 2009; p. 56.

15. Rolshausen, P.E.; Gubler, W.D. Use of boron for the control of Eutypa dieback of grapevines. Plant Dis. 2005, 89, 734-738.

16. John, S.; Wicks, T.J.; Hunt, J.S.; Lorimer, M.F.; Oakey, H.; Scott, E.S. Protection of grapevine pruning wounds from infection by Eutypa lata using Trichoderma harzianum and Fusarium lateritium. Australas. Plant Pathol. 2005, 34, 569-575.

17. Bester, W.; Crous, P.W.; Fourie, P.H. Evaluation of fungicides as potential grapevine pruning wound protectants against Botryosphaeria species. Australas. Plant Pathol. 2007, 36, 73-77. 
18. Sosnowski, M.R.; Creaser, M.L.; Wicks, T.J.; Lardner, R.; Scott, E.S. Protection of grapevine pruning wounds from infection by Eutypa lata. Aust. J. Grape Wine Res. 2008, 14, 134-142.

19. Kotze, C.; Van Niekerk, J.; Mostert, L.; Halleen, F.; Fourie, P. Evaluation of biocontrol agents for grapevine pruning wound protection against trunk pathogen infection. Phytopathol. Mediterr. 2011, 50, S247-S263.

20. Fourie, P.H.; Halleen, F. Proactive control of Petri disease of grapevine through treatment of propagation material. Plant Dis. 2004, 88, 1241-1245.

21. Fourie, P.H.; Halleen, F. Chemical and biological protection of grapevine propagation material from trunk disease pathogens. Eur. J. Plant Pathol. 2006, 116, 255-265.

22. Gramaje, D.; Armengol, J. Fungal trunk pathogens in the grapevine propagation process: Potential inoculum sources, detection, identification, and management strategies. Plant Dis. 2011, 95, 1040-1055.

23. Carter, M.V. Eutypa Dieback. In Compendium of Grape Diseases; Pearson, R.C., Goheen, A.C., Eds.; APS Press: St. Paul, MN, USA, 1988; pp. 32-34.

24. Tsoupras, G.; de Angelis, P.; Zesiger, T.; Renoud, J.M.; Tabacchi, R. Biologically-active natural acetylenes from the culture medium of Eutypa lata. Bioact. Mol. 1988, 93-100.

25. Renoud, J.M.; Tsoupras, G.; Stoeckli-Evans, H.; Tabacchi, R. A novel allenic epoxycyclohexane and related compounds from Eutypa lata (Pers:F.) Tul. Helv.Chim. Acta 1989, 72, 1262-1267.

26. Renoud, J.M.; Tsoupras, G.; Tabacchi, R. Biologically active natural acetylenic compounds from Eutypa lata (Pers:F.) Tul. Helv. Chim. Acta 1989, 72, 929-932.

27. Molyneux, R.J.; Mahoney, N.; Bayman, P.; Wong, R.Y.; Meyer, K.; Irelan, N. Eutypa dieback in grapevines: Differential production of acetylenic phenol metabolites by strains of Eutypa lata. J. Agric. Food Chem. 2002, 50, 1393-1399.

28. Mahoney, N.; Lardner, R.; Molyneux, R.J.; Scott, E.S.; Smith, L.R.; Schoch, T.K. Phenolic and heterocyclic metabolite profiles of the grapevine pathogen Eutypa lata. Phytochemistry 2003, $64,475-484$.

29. Defrancq, E.; Gordon, J.; Brodard, A.; Tabacchi, R. The synthesis of a novel epoxycyclohexane from the fungus Eutypa lata (Pers:F) Tul. Helv. Chim. Acta 1992, 75, 276-281.

30. Chapuis, L.; Corio-Costet, M.F.; Malosse, C. Sterol composition of the woody plant pathogenic fungus Eutypa lata. Phytochemistry 1996, 42, 1599-1601.

31. Smith, L.R.; Mahoney, N.; Molyneux, R.J. Synthesis and structure-phytotoxicity relationships of acetylenic phenols and chromene metabolites, and their analogues, from the grapevine pathogen Eutypa lata.J. Nat. Prod. 2003, 66, 169-176.

32. Kim, J.H.; Mahoney, N.; Chan, K.L.; Molyneux, R.J.; Campbell, B.C. Secondary metabolites of the grapevine pathogen Eutypa lata inhibit mitochondrial respiration, based on a model bioassay using the yeast Saccharomyces cerevisiae. Curr. Microbiol. 2004, 49, 282-287.

33. Amborabé, B.E.; Fleurat-Lessard, P.; Bonmort, J.; Roustan, J.P.; Roblin, G. Effects of eutypine, a toxin from Eutypa lata, on plant cell plasma membrane: Possible subsequent implication in disease development. Plant Physiol. Biochem. (Paris) 2001, 39, 51-58.

34. Deswarte, C.; Eychenne, J.; Davy de Virville, J.; Roustan, J.; Moreau, F.; Fallot, J. Protonophoric activity of eutypine, a toxin from Eutypa lata, in plant mitochondria. Arch. Biochem. Biophys. 1996, 334, 200-205. 
35. Deswarte, C.; Canut, H.; Klaebe, A.; Roustain, J.P.; Fallot, J. Transport, cytoplasmatic accumulation, and mechanism of action of the toxic eutypine in Vitis vinifera cells. J. Plant Pathol. 1996, 149, 336-342.

36. Fallot, J.; Deswarte, C.; Dalmayrac, S.; Colrat, S.; Roustan, J.P. L'Eutypiose de la vigne: Isolement d'une molécule synthétisée par Eutypa lata et toxique pour la vigne. Comptes Rendus Acad. Sci. Ser. III 1997, 320, 149-158.

37. Colrat, S.; Deswarte, C.; Latché, A.; Klaebe, A.; Bouzayen, M.; Fallot, J.; Roustan, J.P. Enzymic detoxification of eutypine, a toxin from Eutypa lata, by Vitis vinifera cells. Partial purification of an NADPH-dependent aldehyde reductase. Planta 1999, 207, 544-550.

38. Afifi, M.; Monje, M.C.; Legrand, V.; Roustan, J.P. Metabolisation of eutypine by plant tissues: An HPLC determination. Anal. Chim. Acta 2004, 513, 21-27.

39. Colrat, S.; Latché, A.; Guis, M.; Pech, J.C.; Bouzayen, M.; Fallot, J.; Roustan, J.P. Purification and characterization of a NADPH-dependent aldehyde reductase from mung bean that detoxifies eutypine, a toxin from Eutypa lata. Plant Physiol. 1999, 119, 621-626.

40. Legrand, V.; Dalmayrac, S.; Latché, A.; Pech, J.C.; Bouzayen, M.; Fallot, J.; Torregrosa, L.; Bouquet, A.; Roustan, J.P. Constitutive expression of $V r$-ERE gene in transformed grapevines confers enhanced resistance to eutypine, a toxin from Eutypa lata. Plant Sci. 2003, 164, 809-814.

41. Guillen, P.; Guis, M.; Martínez-Reina, G.; Colrat, S.; Dalmayrac, S.; Deswarte, C.; Bouzayen, M.; Roustan, J.P.; Fallot, J.; Pech, J.C.; et al. A novel NADPH-dependent aldehyde reductase gene from Vigna radiata confers resistance to the grapevine fungal toxin eutypine. Plant J. 1998, 16, 335-343.

42. Lecomte, P.; Péros, J.P.; Blancard, D.; Bastien, N.; Délye, C. PCR assays that identify the grapevine dieback fungus Eutypa lata. Appl. Environ. Microbiol. 2000, 66, 4475-4480.

43. Lardner, R.; Stummer, B.E.; Sosnowski, M.R.; Scott, E.S. Molecular identification and detection of Eutypa lata in grapevine. Mycol. Res. 2005, 109, 799-808.

44. Sosnowski, M.R.; Shtienberg, D.; Creaser, M.L.; Wicks, T.J.; Lardner, R.; Scott, E.S. The influence of climate on foliar symptoms of eutypa dieback in grapevines. Phytopathology 2007, 97, 1284-1289.

45. Viala, P. Recherches sur les maladies de la vigne. Esca. Annales des Epiphyties 1926, 12, 5-108.

46. Marsais, P. Maladie de l'esca. Rev. de Vit. 1923, 59, 8-14.

47. Surico, G. Towards a redefinition of the diseases within the esca complex of grapevine. Phytopathol. Mediterr. 2009, 48, S487-S490.

48. Mostert, L.; Groenewald, J.Z.; Summerbell, R.C.; Gams, W.; Crous, P.W. Taxonomy and pathology of Togninia (Diaporthales) and its Phaeoacremonium anamorphs. Stud. Mycol. 2006, $54,1-115$.

49. Essakhi, S.; Mugnai, L.; Crous, P.W.; Groenewald, J.Z.; Surico, G. Molecular and phenotypic characterisation of novel Phaeoacremonium species isolated from esca diseased grapevines. Persoonia 2008, 21, 119-134.

50. Graham, A.B.; Johnston, P.R.; Weir, B.S. Three new Phaeoacremonium species on grapevines in New Zealand. Australas. Plant Pathol. 2009, 38, 505-513. 
51. Gramaje, D.; Armengol, J.; Mohammadi, H.; Banihashemi, Z.; Mostert, L. Novel Phaeoacremonium species associated with Petri disease and esca of grapevine in Iran and Spain. Mycologia 2009, 101, 920-929.

52. Surico, G.; Mugnai, L.; Marchi, G. The Esca Disease Complex. In Integrated Management of Diseases Caused by Fungi, Phytoplasma and Bacteria; Springer: Heidelberg, Germany, 2008; pp. 119-136.

53. Luque, J.; Martos, S.; Aroca, A.; Raposo, R.; Garcia-Figueres, F. Symptoms and fungi associated with declining mature grapevine plants in northeast Spain. J. Plant Pathol. 2009, 91, 381-390.

54. Evidente, A.; Sparapano, L.; Andolfi, A.; Bruno, G. Two naphthalenone pentaketides from liquid cultures of Phaeoacremonium aleophilum, a fungus associated with esca of grapevine. Phytopathol. Mediterr. 2000, 39, 162-168.

55. Tabacchi, R.; Fkyerat, A.; Poliart, C.; Dubin, G.M. Phytotoxins from fungi of esca of grapevine. Phytopathol. Mediterr. 2000, 39, 156-161.

56. Evidente, A.; Peduto, F.; Andolfi, A.; Marchi, G.; Mugnai, L.; Surico, G. Fattori di Virulenza dei Funghi Dell'esca. Fitotossine da Phaeomoniella chlamydospora, Phaeoacremonium aleophilum e Fomitiporia mediterranea: Produzione e Attività Biologica. In Il Mal dell'Esca della Vite: Interventi di ricerca e Sperimentazione per il Contenimento Della Malattia. Progetto MesVit; Surico, G., Mugnai, L., Eds.; Arsia Regione Toscana: Firenze, Italy, 2010; pp. 214-231.

57. Abou-Mansour, E.; Couche, E.; Tabacchi, R. Do fungal naphthalenones have a role in the development of esca symptoms? Phytopathol. Mediterr. 2004, 43, 75-82.

58. Sparapano, L.; Bruno, G.; Graniti, A. Effects on plants of metabolites produced in culture by Phaeoacremonium chlamydosporum, P. aleophilum and Fomitiporia punctata. Phytopathol. Mediterr. 2000, 39, 169-177.

59. Seviour, T.; Lambert, L.K.; Pijuan, M.; Yuan, Z. Structural determination of a key exopolysaccharide in mixed culture aerobic sludge granules using NMR spectroscopy, Environ. Sci. Technol. 2010, 44, 8964-8970.

60. Hogdson, R.; Peterson, W.H.; Riker, A.J. The toxicity of polysaccharides and other large molecules to tomato cuttings. Phytopathology 1949, 39, 47-62.

61. Harborne, J.B. Toxins of Plant-Fungal Interaction. In Handbook of Natural Toxins: Plant and Fungal Toxins; Keelr, R.F., Tu, A., Eds.; Marcel Dekker: New York, NY, USA, 1983; Volume 1, pp. 743-782.

62. Denny, T.P. Involvement of bacterial polysaccharides in plant pathogenesis. Ann. Rev. Phytopathol. 1995, 33, 173-197.

63. van Alfen, N.K. Reassessment of plant wilt toxins. Ann. Rev. Phytopathol. 1989, 27, 533-550.

64. Spalding, D.H.; Bruehl, G.W.; Foster, R.J. Possible role of pectinolytic enzymes and polysaccharide in pathogenesis by Cephalosporium gramineum in wheat. Phytopathology 1961, 51, 227-235.

65. McWain, P.; Gregory, G.F. A neutral mannan from Ceratocystis fagacearum culture filtrate. Phytochemistry 1972, 11, 2609-2612.

66. Strobel, G.A.; van Alfen, N.; Hapner, K.D.; McNeil, M.; Albersheim, P. Some phytotoxic glycopeptides from Ceratocystis ulmi, the Dutch Elm Disease pathogen. Biochim. Biophys. Acta 1978, 538, 60-75. 
67. Thomas, C.A. A wilt-inducing polysaccharide from Fusarium solani f. eumartii. Phytopathology 1949, 39, 572-579.

68. Keen, N.T.; Wang, M.C.; Bartnicki-Garcia, S.; Zentmeyer, G.A. Phytotoxicity of myco-laminarans- $\beta-1,3$-glucans from Phytophthora spp. Physiol. Plant Pathol. 1975, 7, 91-97.

69. Woodward, J.R.; Keane, P.J.; Stone, B.A. Structures and properties of wilt-inducing polysaccharides from Phytophthora spp. Physiol. Plant Pathol. 1980, 16, 439-454.

70. Barbosa, A.M.; Steluti, R.M.; Dekker, R.F.H.; Cardoso, M.S.; Corradi da Silva, M.L. Structural characterization of Botryosphaeran: A $(1 \rightarrow 3 ; 1 \rightarrow 6)-\beta$-D-glucan produced by the ascomyceteous fungus, Botryosphaeria sp. Carbohyd. Res. 2003, 338, 1691-1698.

71. Rudolph, K.W.E.; Gross, M.; Neugebauer, M.; Hokawat, S.; Zachowski, A.; Wanddra, K.; Klement, Z. Extracellular Polysaccharides as Determinants of Leaf Spot Diseases Caused by Pseudomonads and Xanthomonads. In Phytotoxins and Plant Pathogenesis, NATO ASI Series, Series H: Cell Biology; Graniti, A., Durbin, R.D., Ballio, A., Eds.; Springer Verlag: Berlin, Germany, 1989; pp. 177-218.

72. Corsaro, M.M.; de Castro, C.; Evidente, A.; Lanzetta, R.; Molinaro, A.; Parrilli, M.; Sparapano, L. Phytotoxic extracellular polysaccharide fractions from Cryphonectria parasitica (Murr.) Barr. Carbohyd. Polym. 1998, 37, 167-172.

73. Corsaro, M.M.; de Castro, C.; Evidente, A.; Lanzetta, R.; Molinaro, A.; Mugnai, L.; Parrilli, M.; Surico, G. Chemical structure of two phytotoxic exopolysaccharides produced by Phomopsis foeniculi. Carbohydr. Res. 1998, 308, 349-357.

74. Martos, S.; Andolfi, A.; Luque, J.; Mugnai, L.; Surico, G.; Evidente, A. Production of phytotoxic metabolites by five species of Botryosphaeriaceae causing decline on grapevine, with special interest in the species Neofusicoccum luteum and N. parvum. Eur. J. Plant Pathol. 2008, $121,451-461$.

75. Leathers, T.D. Pullulan. In Polysaccharides II: Polysaccharides from Eukaryotes; Vandamme, E.J., de Baets, S., Steinbuchel, A., Eds.; Wiley-VCH: Weinheim, Germany, 2002; Volume 6, pp. 1-35.

76. Campbell, B.S.; Siddique, A.B.M.; McDougall, B.M.; Seviour, R.J. Which morphological forms of the fungus Aureobasidium pullulans are responsible for pullulan production? FEMS Microb. Lett. 2004, 232, 225-228.

77. Bruno, G.; Sparapano, L.; Graniti, A.A. Effects of three esca-associated fungi on Vitis vinifera L.: IV. Diffusion through the xylem of metabolites produced by two tracheiphilous fungi in the woody tissue of grapevine leads to esca-like symptoms on leaves and berries. Physiol. Mol. Plant Pathol. 2007, 71, 106-124.

78. Luini, E.; Fleurat-Lessard, P.; Rousseau, L.; Roblin, G.; Berjeaud, J. Inhibitory effects of polypeptides secreted by the grapevine pathogens Phaeomoniella chlamydospora and Phaeoacremonium aleophilum on plant cell activities. Physiol. Mol. Plant Pathol. 2010, 74, 403-411.

79. Fleurat-Lessard, P.; Luini, E.; Berjeaud, J.M.; Roblin, G. Diagnosis of grapevine esca disease by immunological detection of Phaeomoniella chlamydospora. Aust. J. Grape Wine Res. 2010, $16,455-463$. 
80. White, C.L. The Characterization of the Basidiomycetes and Other Fungi Associated with Esca of Grapevines in South Africa. Master Thesis, Stellenbosch University, Stellenbosch, South Africa, 2010.

81. Castro, F.A.V.; Mariani, D.; Panek, A.D.; Eleutherio, E.C.A.; Pereira, M.D. Cytotoxicity mechanism of two naphthoquinones (menadione and plumbagin) in Saccharomyces cerevisiae. PLoS One 2008, 3, doi:10.1371/journal.pone.0003999.

82. Butler, M.; Gardiner, R.; Day, A. Melanin synthesis by Sclerotinia sclerotiorum. Mycologia 2009, 101, 296-304.

83. Wheeler, M.H.; Abramczyk, D.; Puckhaber, L.S.; Naruse M.; Ebizuka, Y.; Fujii, I.; Szaniszlo, P.J. New biosynthetic step in the melanin pathway of Wangiella (Exophiala) dermatitidis: Evidence for 2-acetyl-1,3,6,8-tetrahydroxynaphthalene as a novel precursor. Eukaryot. Cell 2008, 7, 1699-1711.

84. Kwon-Chung, K.J.; Polacheck, I. Melanin-lacking mutants of Cryptococcus neoformans and their virulence for mice. J. Bacteriol. 1982, 150, 1414-1421.

85. Geis, P.A.; Wheeler, M.H.; Szaniszlo, P.J. Pentaketide metabolites of melanin synthesis in the dematiaceous fungus Wangiella dermatitidis. Arch. Microbiol. 1984, 137, 324-328.

86. Dixon, D.M.; Szaniszlo, P.J.; Polak, A. Dihydroxynaphthalene (DHN) Melanin and its Relationship with Virulence in the Early Stages of Phaeohyphomycosis. In The Fungal Spore and Disease Initiation in Plants and Animals; Cole, G.T., Hock, H.C., Eds.; Plenum Press: New York, NY, USA, 1991; pp. 297-318.

87. Durrell, L.W. The composition and structure of walls of dark fungus spores. Mycopathol. Mycol. Appl. 1964, 23, 339-345.

88. Bürki, N.; Michel, A.; Tabacchi, R. Naphthalenones and isocoumarins of the fungus Ceratocystis fimbriata sp. platani. Phytopathol. Mediterr. 2003, 42, 191-198.

89. Oberth, C.H.; Jones, A.D.; Shibamoto, T. Retro-Michael Fragmentation in Tandem Mass Spectrometry of Modified Peptides. In Proceedings of the 40th ASMS Conference on Mass Spectrometry, Washington, DC, USA, 31 May-5 June 1992; p. 1715.

90. Scandalios, J.G. Response of plant antioxidant defense genes to environment stress. Adv. Genet. 1990, 28, 2-35.

91. Dangl, J.L.; Deetrich, R.A.; Richberg, M.H. Death don't have no mercy: Cell death programs in plant-microbe interactions. Plant Cell 1996, 8, 1793-1807.

92. Thomson, R.H. Naturally Occuring Quinones; Academic Press: London, UK, 1971; pp. 39-92.

93. Medentsev, A.G.; Akimenko, V.K. Naphthoquinone metabolites of the fungi. Phytochemistry 1998, 47, 933-959.

94. Lattanzio, V.; Lattanzio, V.M.T.; Cardinali, A. Role of Phenolics in the Resistance Mechanisms of Plants Against Fungal Pathogens and Insects. In Phytochemistry: Advances in Research; Imperato, F., Ed.; Research Signpost: Kerala, India, 2006; pp. 23-67.

95. Kurahashi, Y.; Sakawa, S.; Kinbara, T.; Tanaka, K.; Kagabu, S. Biological activity of carpropamid (KTU 3616): A new fungicide for rice blast disease. J. Pest. Sci. 1997, 22, 108-112.

96. Yumita, T.; Shojiand, A.; Yamamoto, I. Metabolism of mepronil (basitac) in rice plants. J. Pest. Sci. 1983, 5, 347-349. 
97. Petit, A.N.; Vaillant, N.; Boulay, M.; Clement, C.; Fontaine, F. Alteration of photosynthesis in grapevines affected by esca. Phytopathology 2006, 96, 1060-1066.

98. Mattii, G.B.; Bardi, E.; Calabrese, C.; Giorgini, A. Alterazioni Degli Scambi Gassosi Causati dal Mal Dell'esca-Misurazioni su Foglia Singola e SULL'INTERA Chioma di Piante di Vite in Vaso. 2010. In Il mal Dell'esca Della Vite: Interventi di Ricerca e Sperimentazione per il Contenimento Della Malattia. Progetto MesVit; Surico, G., Mugnai, L., Eds.; Arsia Regione Toscana: Firenze, Italy, 2010; pp. 241-260.

99. Calamai, L.; Mattii, G.; Mugnai, L.; Surico, G. Physiological alterations in esca-diseased vines and the detection of scytalone and isosclerone in the tiger-striped vine leaves. Phytopathol. Mediterr. 2009, 48, 168-169.

100. Calamai, L.; Zini, E.; Cantalupo, L.; Comparini, C. Monitoraggio di Marcatori Chimici di Stress Idrico in Foglie di Vite Con Sintomi di Esca. In Il Mal dell'esca Della Vite: Interventi di Ricerca e Sperimentazione per il Contenimento Della Malattia. Progetto MesVit; Surico, G., Mugnai, L., Eds.; Arsia Regione Toscana: Firenze, Italy, 2010; pp. 232-240.

101. Dimond, A.E.; Waggoner, P.E. On the nature and role of vivotoxins in plant diseases. Phytopathology 1953, 43, 229-235.

102. Bruno, G.; Sparapano, L. Effects of three esca-associated fungi on Vitis vinifera L. II. Characterization of biomolecules in xylem sap and leaves of healthy and diseased vines. Physiol. Mol. Plant Pathology 2007, 69, 195-208.

103. Andolfi, A.; Cimmino, A.; Evidente, A.; Iannacone, M.; Capparelli, R.; Mugnai, L.; Surico, G. A new flow cytometry technique to identify Phaeomoniella chlamydospora exopolysaccharides and study mechanisms of esca grapevine foliar symptoms. Plant Dis. 2009, 93, 680-684.

104. Santos, C.; Fragoeiro, S.; Valentim, H.; Phillips, A. Phenotypic characterisation of Phaeacremonium and Phaemoniella strains isolated from grapevines: Enzyme production and virulence of extra-cellular filtrate on grapevine callus. Sci. Hortic. 2006, 107, 123-130.

105. Bruno, G.; Sparapano, L. Effects of three esca associated fungi on Vitis vinifera L.: III. Enzymes produced by the pathogens and their role in fungus-to-plant or in fungus-to-fungus interactions. Physiol. Mol. Plant Pathol. 2006, 69, 182-194.

106. Lima, M.R.M.; Felgueiras, M.L.; Graça, G.; João, E.A.R.; Barros, A.; Gil, G.; Dias, A.C.P. NMR metabolomics of esca disease-affected Vitis vinifera cv. Alvarinho leaves. J. Exp. Bot. 2010, 61, 4033-4042.

107. Úrbez-Torres, J.R.; Gubler, W.D.; Luque, J. First report of Botryosphaeria iberica and Botryosphaeria viticola associated with grapevine decline in California. Plant Dis. 2007, 91, doi:10.1094/PDIS-91-6-0772C.

108. Úrbez-Torres, J.R. The status of Botryosphaeriaceae species infecting grapevines. Phytopathol. Mediterr. 2011, 50, S5-S45.

109. Hewitt, R.D. Diplodia Cane Dieback and Bunch Rot. In Compendium of Grape Diseases; The American Phytopathological Society (APS) Press: St. Paul, MN, USA, 1988; pp. 25-26.

110. Phillips, A.J.L. Botryosphaeria dothidea and other fungi associated with excoriose and dieback of grapevines in Portugal. J. Phytopathol. 1998, 146, 327-332.

111. Phillips, A.J.L. Botryosphaeria species associated with diseases of grapevines in Portugal. Phytopathol. Mediterr. 2002, 41, 3-18. 
112. Larignon, P.; Fulchic, R.; Cere, L.; Dubos, B. Observation on black dead arm in French vineyards. Phytopathol. Mediterr. 2001, 40, S336-S342.

113. Castillo-Pando, M.; Somers, A.; Green, C.D.; Priest, M.; Sriskanthades, M. Fungi associated with dieback of Semillon grapevines in the Hunter Valley of New South Wales. Australas. Plant Pathol. 2001, 30, 59-63.

114. Taylor, A.; Hardy, G.E.S.; Wood, P.; Burgess, T. Identification and pathogenicity of Botryosphaeria species associated with grapevine decline in Western Australia. Australas. Plant Pathol. 2005, 34, 187-195.

115. Wunderlich, N.; Steel, C.C.; Ash, G.; Raman, H.; Savocchia, S. Identification of Botryosphaeria spp. and First Report of Dothiorella Viticola ("Botryosphaeria" Viticola) Associated with Bunch Rot in Australia. In Proceedings of the 6th International Workshop on Grapevine Trunk Diseases, Florence, Italy, 1-3 September 2008.

116. Savocchia, S.; Steel, C.C.; Stodart, B.J.; Somers, A. Pathogenicity of Botryosphaeria species isolated from declining grapevines in sub-tropical regions of eastern Australia. Vitis 2007, $46,27-32$.

117. Corradi da Silva, M.L.; Izeli, N.L.; Martinez, P.F.; Silva, I.R.; Costantino, C.J.L.; Cardoso, M.S.; Barbosa, A.M.; Dekker, R.F.H.; da Silva, G.V.J. Purification and structural characterisation of $(1 \rightarrow 3 ; 1 \rightarrow 6)-\beta$-D-glucans (botryosphaerans) from Botryosphaeria rhodina grown on sucrose and fructose as carbon sources. a comparative study. Carbohyd. Polym. 2005, 61, 10-17.

118. Evidente, A.; Motta, A. Phytotoxins from Fungi Pathogenic for Agrarian, Forestal and Weedy Plants. In Bioactive Compounds from Natural Sources: Isolation, Characterization, and Biological Properties; Taylor \& Francis Group: London, UK, 2001; pp. 473-525.

119. Evidente, A.; Punzo, B.; Andolfi, A.; Cimmino, A.; Melck, D.; Luque, J. Lipophilic phytotoxins produced by Neofusicoccum parvum, a grapevine canker agent. Phytopathol. Mediterr. 2010, 49, 74-79.

120. Aldridge, D.C.; Galt, S.; Giles, D.; Turner, W.B. Metabolites of Lasiodiplodia theobromae. J. Chem. Soc. 1971, 1623-1627.

121. Kimura, Y.; Tamura, S. Isolation of 1- $\beta$-phenyllactic acid and tyrosol as plant-growth regulators from Gloeosporium laeticolor. Agric. Biol. Chem. 1973, 37, 2925-2925.

122. Morita, T.; Aoki, H. Isosclerone, a new metabolite of Sclerotinia sclerotiorum (Lib.) De Bary. Agric. Biol. Chem. 1974, 38, 1501-1504.

123. Cole, R.J.; Cox, R.H. Handbook of Toxic Fungal Metabolites; Academic Press: New York, NY, USA, 1981; volume 3, pp. 623-624.

124. Turner, W.B.; Aldridge, D.C. Fungal Metabolites II; Academic Press: London, UK, 1983; pp. 82-109.

125. Venkatasubbaiah, P.; Chilton, W.S. Phytotoxins of Botryosphaeria obtusa. J. Nat. Prod. 1990, $53,1628-1630$.

126. Devys, M.; Barbier, M.; Bousquet, J.F.; Kollmann, A. Isolation of the new (-)-(3R,4S)-4hydroxymellein from the fungus Septoria nodorum Berk. Z. Naturforsch. B. 1992, 47, 779-881.

127. Cabras, A.; Mannoni, M.A.; Serra, S.; Andolfi, A.; Fiore, M. Occurrence, isolation and biological activity of phytotoxic metabolites produced in vitro by Sphaeropsis sapinea, pathogenic of Pinus radiata. Eur. J. Plant Pathol. 2006, 115, 187-193. 
128. Venkatasubbaiah, P.; Sutton, T.B.; Chilton, W.S. Effect of phytotoxins produced by Botryosphaeria obtusa, the cause of black rot of apple fruit and frogeye leaf spot. Phytopathology 1991, 81, 243-247.

129. Lecomte, P.; Leyo, M.; Louvet, G.; Corio-Costet, M.F.; Gaudillère, J.P.; Blancard, D. Le Black Dead Arm, genèse des symptômes. Phytoma La Défense des Végetaux 2005, 587, 29-37.

130. Djoukeng, J.D.; Polli, S.; Larignon, P.; Mansour, E.A. Identification of phytotoxins from Botryosphaeria obtusa, a pathogen of black dead arm disease of grapevine. Eur. J. Plant Pathol. 2009, 124, 303-308.

131. Capasso, R.; Cristinzio, G.; Evidente, A.; Scognamiglio, F. Isolation, spectroscopy and selective phytotoxic effects of polyphenols from vegetable waste waters. Phytochemistry 1992, $31,4125-4128$.

132. Spagnolo, A.; Marchi, G.; Peduto, F.; Phillips, A.J.L.; Surico, G. Detection of Botryosphaeriaceae species within grapevine woody tissues by nested PCR, with particular emphasis on the Neofusicoccum parvum/N. ribis complex. Eur. J. Plant Pathol. 2011, 129, 485-500.

133. Cristinzio, G. Gravi attacchi di Botryosphaeria obtusa su vite in provincia di Isernia. Inf. Fitopatol. 1978, 6, 21-23.

134. Lehoczky, J. Black Dead Arm. In Compendium of Grape Diseases; Pearson, R.C., Goheen, A.C., Eds.; The American Phytopathological Society (APS) Press: St. Paul, MN, USA, 1988; p. 35.

135. Marchi, G.; Peduto, F.; Mugnai, L.; di Marco, S.; Calzarano, F.; Surico, G. Some observations on the relationship of manifest and hidden esca to rainfall. Phytopathol. Mediterr. 2006, $45,117-126$.

(C) 2011 by the authors; licensee MDPI, Basel, Switzerland. This article is an open access article distributed under the terms and conditions of the Creative Commons Attribution license (http://creativecommons.org/licenses/by/3.0/). 